\title{
Aerosol Optical Properties over an Urban Site in Central China Determined Using Ground-based Sun Photometer Measurements
}

\author{
Chao Liu ${ }^{1,2}$, Leiku Yang ${ }^{1 *}$, Huizheng Che ${ }^{2 * *}$, Xiangao Xia ${ }^{3,4}$, Hujia Zhao ${ }^{2,5}$, Hong Wang ${ }^{2}$, \\ Ke Gui ${ }^{2}$, Yu Zheng ${ }^{2,6}$, Tianze Sun ${ }^{2}$, Xiaopan $\mathrm{Li}^{2}$, Zhizhong Sheng ${ }^{2}$, Han Wang ${ }^{1}$, Xiaofeng Lu ${ }^{1}$, \\ Xiaoye Zhang ${ }^{2}$ \\ ${ }^{1}$ School of Surveying and Land Information Engineering, Henan Polytechnic University, Henan 454000, China \\ ${ }^{2}$ State Key Laboratory of Severe Weather (LASW), Key Laboratory of Atmospheric Chemistry (LAC), Chinese Academy of \\ Meteorological Sciences, Beijing 100081, China \\ ${ }^{3}$ Laboratory for Middle Atmosphere and Global Environment Observation (LAGEO), Institute of Atmospheric Physics, \\ Chinese Academy of Sciences, Beijing 100029, China \\ ${ }^{4}$ School of Geoscience University of Chinese Academy of Science, Beijing 100049, China \\ ${ }^{5}$ Institute of Atmospheric Environment, China Meteorological Administration, Shenyang 110016, China \\ ${ }^{6}$ Collaborative Innovation Center on Forecast and Evaluation of Meteorological Disasters, Nanjing University of \\ Information Science and Technology, Nanjing 210044, China
}

\begin{abstract}
Sun photometer measurements taken in urban Jiaozuo in central China from July 2016 to February 2018 were used to investigate the aerosol optical and microphysical properties, including the climatological variation in properties, the types of aerosols and the properties during haze and dust events. The mean annual aerosol optical depth at $440 \mathrm{~nm}\left(\mathrm{AOD}_{440 \mathrm{~nm}}\right)$ and the Ångström exponent $\left(\mathrm{AE}_{440-870 \mathrm{~nm}}\right)$ were $0.84 \pm 0.55$ and $1.12 \pm 0.17$, respectively. The highest AOD occurred in summer, which may be associated with the hygroscopic growth of aerosols during enhanced relative humidity. Accordingly, a high volume of fine-mode particles was observed during this season. In addition, carbonaceous aerosols from biomass burning increased the volume of fine particles in June and September, but coarse-mode particles (mainly dust) dominated during spring, especially in May, with a maximum volume of $0.16 \mu \mathrm{m}^{3} \mu \mathrm{m}^{-2}$. At $440 \mathrm{~nm}$, the mean seasonal single scattering albedo $\left(\mathrm{SSA}_{440 \mathrm{~nm}}\right)$ was lower in spring $(0.87 \pm 0.05)$ and higher in summer $(0.95 \pm 0.04)$, whereas the absorption aerosol optical depth $\left(\mathrm{AAOD}_{440 \mathrm{~nm}}\right)$ displayed the opposite pattern, being higher in spring $(0.079 \pm$ $0.019)$ and lower in summer $(0.045 \pm 0.021)$. The increased absorptivity in spring and the strong scattering ability in summer of aerosols in this area may be related to particles originating from different sources. Using the method of classification based on the fine-mode fraction (FMF), SSA and AE, absorbing aerosols, both fine and mixed, were identified as the predominant type of particulate matter. The site was influenced not only by anthropogenic aerosols from local emissions and the surrounding regions but also by dust from northwestern China. The mean AOD and AE were 1.66 and 1.38 on hazy days, while a slightly low AOD of 0.95 and an extremely low AE of 0.18 were exhibited on dusty days. This study provides a comprehensive understanding of aerosol properties in this area, and the results will help to optimize the satellite aerosol inversion algorithm and promote regional climate change research.
\end{abstract}

Keywords: Aerosol optical properties; Aerosol classification; Sun photometer measurements; Jiaozuo.

\footnotetext{
* Corresponding author. Tel.: 86-0391-3987661; Fax: 86-0391-3987663

E-mail address: yanglk@hpu.edu.cn

** Corresponding author.

Tel.: 86-10-58993116; Fax: 86-10-62176414

E-mail address: chehz@cma.gov.cn
}

\section{INTRODUCTION}

Aerosol particles are an important component of the earth-atmosphere system, directly influencing its radiative energy balance by absorbing and scattering solar radiation (Kaufman et al., 1997), and indirectly altering the microphysical properties of cloud by acting as cloud condensation nuclei (Twomey et al., 1984). In addition, atmospheric aerosol, as a major pollutant in the atmosphere, can cause various atmospheric environmental problems, 
such as the degradation of air quality (Seneviratne et al., 2017) and visibility (Che et al., 2007), ultimately threatening human health (Pope and Dockery, 2006; Kumar et al., 2015). Therefore, long-term measurements of aerosol optical properties need to be conducted for further exploring the effects of aerosols on climate change and environmental pollution.

Due to the high variability in the spatial and temporal distribution of the optical and microphysical properties of aerosol particles (Liu et al., 2009; Ma et al., 2011), their impact on Earth's climate is highly uncertain (Schwartz and Andreae, 1996; Hansen et al., 2000). Therefore, a large number of in situ measurements of the optical and microphysical properties is imperative. Satellite remote sensing and ground-based observation are two effective methods for measuring aerosol, each with their own strengths and weaknesses. Satellite remote sensing can detect continuous distributions of aerosol features (e.g., aerosol optical depth (AOD)) (He et al., 2018; Qin et al., 2018; Zhang et al., 2018) and quickly obtain global-scale aerosol information on them regardless of the limits imposed by conditions on the ground; however, some other aerosol optical properties, e.g., absorption aerosol optical depth (AAOD) and absorption Ångström exponent (AAE), are harder to retrieve via this route. Ground-based observation, meanwhile, is an effective approach for characterizing the optical and microphysical properties of aerosols and can achieve high levels of accuracy (Dubovik and King, 2000). Although ground-based observation can only reflect aerosol information within a certain range around a site, a number of global or regional aerosol observation networks have been established worldwide, for example, AERONET (Holben et al., 1998), PHOTONS (Goloub et al., 2008), SKYNET (Nakajima et al., 2003), AEROCAN (Bokoye et al., 2001), and CARSNET (Che et al., 2009, 2015a).

In recent decades, China has experienced a period of rapid economic development that has attracted worldwide attention. Accompanied by the rapid increase in the level of industrialization and urbanization, many cities have encountered severe air pollution with considerable contributions from atmospheric particulate matter (PM) (Chan and Yao, 2008). These aerosol particles are mainly derived from natural sources and anthropogenic emissions. Aerosol particles are not usually homogeneous in most Chinese cities; rather, they are made up of a mixture of absorbing and non-absorbing particles. Absorbing aerosol particles include carbonaceous aerosols produced by coal combustion and biomass burning, as well as iron oxides in mineral dust (Yang et al., 2009). Non-absorbing aerosols comprise not only sulfate and nitrate emitted by the burning of fossil fuel and present in vehicle exhaust, but also ammonium-salt and sea-salt. A great number of studies on aerosol optical properties have been conducted in China, together contributing immensely to our understanding of urban air pollution (Che et al., 2015b; Li et al., 2016; Zhao et al., 2018). For example, Li et al. (2017) studied the optical and microphysical properties of aerosols in summer in northern China; aerosol optical properties and direct radiative forcing in northeastern China were analyzed by
Che et al. (2015c); and Wang et al. (2011) reported seasonal changes in aerosol optical characteristics in different regions of China. However, most studies of this type have concentrated mainly on the Yangtze River Delta (YRD) region (Cheng et al., 2015; Qi et al., 2016; Che et al., 2018), the North China Plain (Che et al., 2014; Zhu et al., 2014; Zheng et al., 2017), northeastern China (Wang et al., 2010; Zhao et al., 2013; Che et al., 2015c), and some other heavily polluted areas (Wang et al., 2015a; Li et al., 2017; Liu et al., 2017). Only a few studies have focused on the aerosol optical properties in central China, due to the limited availability of aerosol observations in this region. Among those few studies, Wang et al. (2015a, b) and Zhang et al. (2017a) used ground-based observation data to study the aerosol optical properties in the areas of Wuhan and Songshan Mountain; yet, to the best of our knowledge, due to a shortage of ground sites or observation, no attempt has been made to investigate the aerosol optical and microphysical properties in an urban region in Henan Province which has suffered from serious air pollution. Crucially, Henan Province is located in the Beijing-Tianjin-Hebei atmospheric transmission channel, meaning its aforementioned serious air pollution may have measurable effects on the air quality over the Beijing-Tianjin-Hebei region, which, socioeconomically, is a highly important part of China. Therefore, it is imperative to study the aerosol optical properties in this area for improving our understanding of local air pollution and regional aerosol-climate interactions.

The purpose of the present reported work was to investigate the aerosol optical properties in Jiaozuo using one and a half years (July 2016-February 2018) of groundbased sun photometer data. Specifically, monthly and seasonal variations of AOD, AAE, AAOD, Ångström exponent (AE), single scattering albedo (SSA), and volume size distribution were analyzed. Additionally, two typical pollution processes (namely, haze and dust) were selected to analyze the aerosol optical properties and identify the sources of aerosol. The results of this study reflect the characteristics of aerosol optical properties in Henan, and to a certain extent even in other urban areas of central China, and may assist in improving the aerosol model over China, optimizing satellite aerosol inversion algorithms and advancing regional climate change research.

\section{SITE, DATA AND METHODS}

\section{Site and Instruments}

Fig. 1 shows the geographic location of the JiaozuoHPU site, which is the only urban site in Henan Province for measuring aerosol optical properties. The site is on the campus of Henan Polytechnic University (HPU) in the city of Jiaozuo, Henan Province, China, where a CE-318 sun photometer (Cimel Electronique, Paris, France) was installed on the roof of the School of Surveying and Land Information Engineering building $\left(35.3^{\circ} \mathrm{N}, 113.3^{\circ} \mathrm{E}, 113 \mathrm{~m}\right)$ in July 2016. Jiaozuo is an industrial city located in northwestern Henan Province, with the Taihang Mountains to the north and the Yellow River to the south, about $60 \mathrm{~km}$ from Zhengzhou (the capital of Henan Province). The climate 


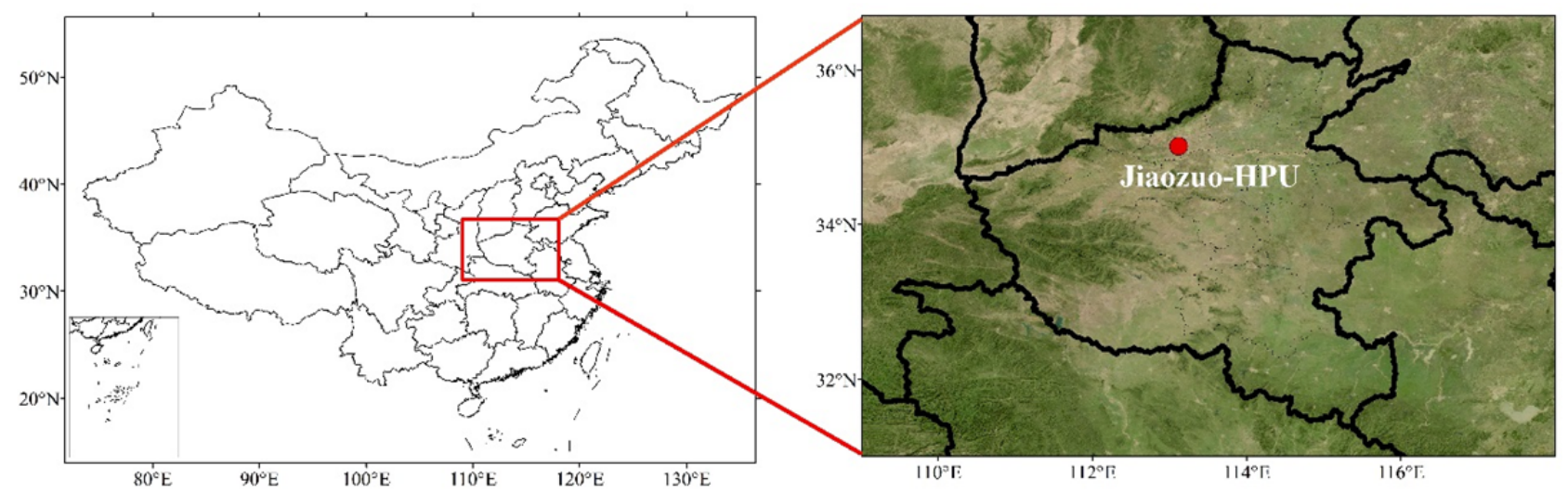

Fig. 1. True color image and locations of Henan Province in China. The red dot denotes the location of Jiaozuo-HPU.

type in Jiaozuo is northern temperate monsoon, typified by abundant rainfall and high temperatures in summer.

The type of sun photometer at Jiaozuo-HPU is CE318NEDPS9 which is termed as polarized version. The sun photometer measures direct solar radiation within a $1.2^{\circ}$ full field-of-view each 15 minutes at nine bands (1640, 1020, 870, 670, 500, 440, 380, 340, and $936 \mathrm{~nm}$ ) (Holben et al., 1998). Measurements in the first eight bands can be used to retrieve the spectral AOD, while total precipitable water vapor can be obtained by the strong water vapor absorption band at $936 \mathrm{~nm}$ (Holben et al., 1998; Che et al., 2009). The Level 1.5 AOD data (cloud-screened AOD, according to Smirnov et al. (2000)) from July 2016 to February 2018 were calculated in the ASTPwin software (Cimel Ltd. Co.). To achieve more reliable results, only AODs observed more than 10 times a day and on 10 days or more in a month were used to calculate the daily and monthly AOD, respectively (Che et al., 2009; Zhao et al., 2013) (Table 1). The AE $(\alpha)$ was derived from the AOD between 440 and $870 \mathrm{~nm}$ by Eq. (1) as follows:

$$
\alpha=-\frac{\ln \left(\tau_{1} / \tau_{2}\right)}{\ln \left(\lambda_{1} / \lambda_{2}\right)}
$$

where $\tau_{1}$ and $\tau_{2}$ are AOD at bands of $\lambda_{1}$ and $\lambda_{2}$ respectively.

In addition, the aerosol microphysical properties and other optical properties, such as SSA, AAOD, AAE, and volume size distribution, were retrieved from the almucantar sky radiance observations at 440,670, 870 and $1020 \mathrm{~nm}$, in conjunction with the measured AOD (Dubovik and King, 2000; Dubovik et al., 2002; Che et al., 2009; Zhao et al., 2013). Among them, AAOD and AAE were calculated by Eqs. (2) and (3) (Russell et al., 2010; Giles et al., 2012).

$$
\operatorname{AAOD}(\lambda)=\operatorname{AOD}(\lambda) \times(1-\operatorname{SSA}(\lambda))
$$

$\mathrm{AAE}=-\mathrm{d} \ln [\mathrm{AAOD}(\lambda)] / \mathrm{d} \ln (\lambda)$

The uncertainty of AOD is approximately $0.01-0.02$ (Eck et al., 1999). The SSA with error of about 0.03 can be retrieved only for $\mathrm{AOD}_{440 \mathrm{~nm}} \geq 0.40$ for solar zenith angles $>50^{\circ}$, to avoid the larger error from the limited information content under lower AODs (Dubovik et al., 2002; Che et al., 2015c).

\section{Data and Analytical Methods}

In this work, in addition to the CE-318 sun photometer data, meteorological data (relative humidity and wind speed) from the China Meteorological Administration and hourly observations of PM concentrations from the China National Environmental Monitoring Centre (http://www. cnemc.cn/) were used to investigate the variation in aerosol optical properties during the two pollution processes of haze and dust. We also used ERA-Interim data (http://apps.ecmwf.int/datasets) downloaded from the European Centre for Medium-Range Weather Forecasts (ECMWF) to analyze the wind field variation at different pressure levels during these pollution processes. Moderate Resolution Imaging Spectroradiometer (MODIS) true color images, with a spatial resolution of $1 \times 1 \mathrm{~km}$, were used to identify dust storms, fog and haze, and cirrus cloud. During the dust episode, the Cloud-Aerosol Lidar and Infrared Pathfinder Satellite Observation (CALIPSO) data was also used to provide vertical profiles of aerosol and cloud layers and aerosol subtypes (Omar et al., 2009). In this work, we mainly analyzed the nighttime CALIPSO V3.40 data. The daytime data can be disturbed by the noise of solar radiation, and was only used for reference.

The 72-h backward trajectories arriving at Jiaozuo-HPU at multiple altitudes were calculated using software called TrajStat (Ngan et al., 2015). We also used Potential Source Contribution Function (PSCF) analysis to further determine the probable source locations of the pollution (Xin, 2016). The Concentration Weighted Trajectory (CWT) method was also applied in this regard, because of its advantages in separating strong and weak sources, which is something PSCF is unable to do. To reduce the level of uncertainty in the values obtained, a weighting function was applied for PSCF and CWT (WPSCF and WCWT, respectively).

\section{RESULTS AND DISCUSSION}

\section{Particle Radius and Volume Size Distributions}

The effective radii of aerosol particles in the Jiaozuo area are listed in Table 1. The monthly effective radii of the 
Table 1. Monthly mean effective radii of aerosols and statistics of Level 1.5 sun direct data for AOD and Ångström exponent at Jiaozuo-HPU.

\begin{tabular}{llllll}
\hline Month & $R_{\text {eff }_{\mathrm{t}}}(\mu \mathrm{m})^{\mathrm{a}}$ & $R_{\text {eff }_{\text {fine }}}(\mu \mathrm{m})^{\mathrm{b}}$ & $R_{\text {eff }_{\text {coarse }}}(\mu \mathrm{m})^{\mathrm{c}}$ & Days & Instantaneous Data \\
\hline Jan & $0.39 \pm 0.13$ & $0.15 \pm 0.03$ & $1.99 \pm 0.36$ & 15 & 553 \\
Feb & $0.41 \pm 0.18$ & $0.14 \pm 0.06$ & $2.06 \pm 0.38$ & 22 & 987 \\
Mar & $0.35 \pm 0.08$ & $0.15 \pm 0.03$ & $2.26 \pm 0.36$ & 14 & 462 \\
Apr & $0.44 \pm 0.15$ & $0.14 \pm 0.05$ & $2.07 \pm 0.61$ & 18 & 673 \\
May & $0.45 \pm 0.13$ & $0.14 \pm 0.02$ & $1.94 \pm 0.56$ & 24 & 924 \\
Jun & $0.30 \pm 0.04$ & $0.19 \pm 0.03$ & $2.43 \pm 0.29$ & 19 & 633 \\
Jul & $0.32 \pm 0.06$ & $0.22 \pm 0.06$ & $2.20 \pm 0.42$ & 36 & 1002 \\
Aug & $0.32 \pm 0.07$ & $0.22 \pm 0.06$ & $2.15 \pm 0.27$ & 28 & 820 \\
Sep & $0.35 \pm 0.11$ & $0.17 \pm 0.04$ & $2.40 \pm 0.26$ & 18 & 758 \\
Oct & $0.32 \pm 0.04$ & $0.21 \pm 0.07$ & $1.93 \pm 0.39$ & 12 & 361 \\
Nov & $0.34 \pm 0.09$ & $0.16 \pm 0.04$ & $1.93 \pm 0.34$ & 39 & 1394 \\
Dec & $0.33 \pm 0.11$ & $0.15 \pm 0.04$ & $2.13 \pm 0.36$ & 44 & 1571 \\
\hline
\end{tabular}

${ }^{\mathrm{a}}$ Effective radii of the total particles. ${ }^{\mathrm{b}}$ Effective radii of fine particles. ${ }^{\mathrm{c}}$ Effective radii of coarse particles.

total particles varied between 0.30 and $0.45 \mu \mathrm{m}$, and the annual mean effective radii of fine-mode and coarse-mode particles were 0.17 and $2.12 \mu \mathrm{m}$, respectively. Remarkably, the fine-mode aerosol effective radii in summer (JuneAugust; $0.19-0.22 \mu \mathrm{m})$ were larger than those in spring (March-May; 0.14-0.15 $\mu \mathrm{m}$ ). This result may be attributable to aerosol hygroscopicity in summer (Che et al., 2018). The monthly mean aerosol volume and size distribution are shown in Fig. 2. Clearly, the size distribution in Jiaozuo has a typical bimodal distribution (Fig. 2(a)). There were slight differences in the peak radii for fine-mode and coarse-mode particles in different months, in which the fine-mode particle radii were mainly concentrated within $0.15-0.35 \mu \mathrm{m}$ and the coarse-mode particle radii within $1.9-3.5 \mu \mathrm{m}$.

From Fig. 2(b), the volume of coarse-mode aerosol particles was obviously higher than that of fine-mode particles in spring. In April and May, coarse-mode particles accounted for the highest proportion, exceeding $65 \%$. The percentage was $66.73 \%$ in May, with a volume of $0.16 \mu \mathrm{m}^{3} \mu \mathrm{m}^{-2}$, which was twice as much as the fine-mode particles. It is also evident, from the size distribution (Fig. 2(a)), that the coarse-mode particles were dominant in April and May, with peak radii of 2.4 and $1.8 \mu \mathrm{m}$, respectively. This may be due to the area being located in the middle and lower reaches of the Yellow River, where the soil is loose and strong winds in spring cause localized sand-blowing weather to enhance the concentration of coarse particles in the atmosphere. In addition, long-distance dust transportation from northwestern China in spring may lead to elevated coarse-particle concentrations (Che et al., 2011). Indeed, Sun et al. (2018) highlighted that Henan Province (Jiaozuo) is located on the pathway of dust particles being transported from northwestern China to the YRD region.

In summer, the volume of coarse particles decreased significantly compared with spring; the percentage in July and August was only about $30 \%$. This may be attributable to the removal of coarse particles by heavy precipitation. The dominance of the fine-mode particles in summer is also apparent in the size distribution and the peak radii moving toward the shortwave infrared wavelengths with the increase in precipitation from June to August (Fig. 3(c)); specifically, the radius increased from 0.2 to $0.35 \mu \mathrm{m}$. The reason is that the size of hygroscopic aerosol, containing sulfate, nitrate and ammonium, is strongly influenced by high relative humidity (Shen et al., 2015; Huang et al., 2016). Furthermore, similar results have been observed in different areas of China, such as the North China Plain (Zhu et al., 2014), northeastern China (Che et al., 2015c), and the YRD region (Che et al., 2018). However, there are slight differences in some of the details. For example, a high volume of fine-mode particles was reported in June and September in the YRD region, owing to the Mei-Yu floods and autumn-rain, but a relatively low volume in July and August thanks to subtropical anticyclonic circulation (Che et al., 2018). The strong precipitation that occurred in July and August in Jiaozuo and the high volume for the fine-mode particles in June and September may have been due to increased concentrations of black carbon aerosol caused by the burning of wheat and corn crops. The volume of fine-mode particles reached $0.16,0.18,0.17$ and $0.14 \mu \mathrm{m}^{3} \mu \mathrm{m}^{-2}$ in June to September, respectively. It should also be noted that Eck et al. (2012) reported that a large size range of fine-mode aerosol particles may be formed by cloud processing.

\section{Aerosol Optical Depth, Angström Exponent and Water Vapor Content}

The annual mean AOD at $440 \mathrm{~nm}$ in Jiaozuo was 0.84 ( 0.73 at $500 \mathrm{~nm})$, with a standard deviation of \pm 0.55 , which suggests high aerosol loading. The AOD in Jiaozuo was higher than that reported for Longfengshan in northeastern China (0.35) (Wang et al., 2010), Xinglong in northern China (0.28) (Zhu et al., 2014), and Songshan Mountain in central China (0.60 at $500 \mathrm{~nm}$ ) (Wang et al., 2015b), the latter of which is regarded as the regional background site in Henan Province, $90 \mathrm{~km}$ south of Jiaozuo-HPU. Additionally, it was also higher than in several metropolises, such as Beijing (0.76) (Che et al., 2015a), Shanghai (0.70) (He et al., 2012a), Hangzhou (0.76) (Che et al., 2018), and Shenyang 

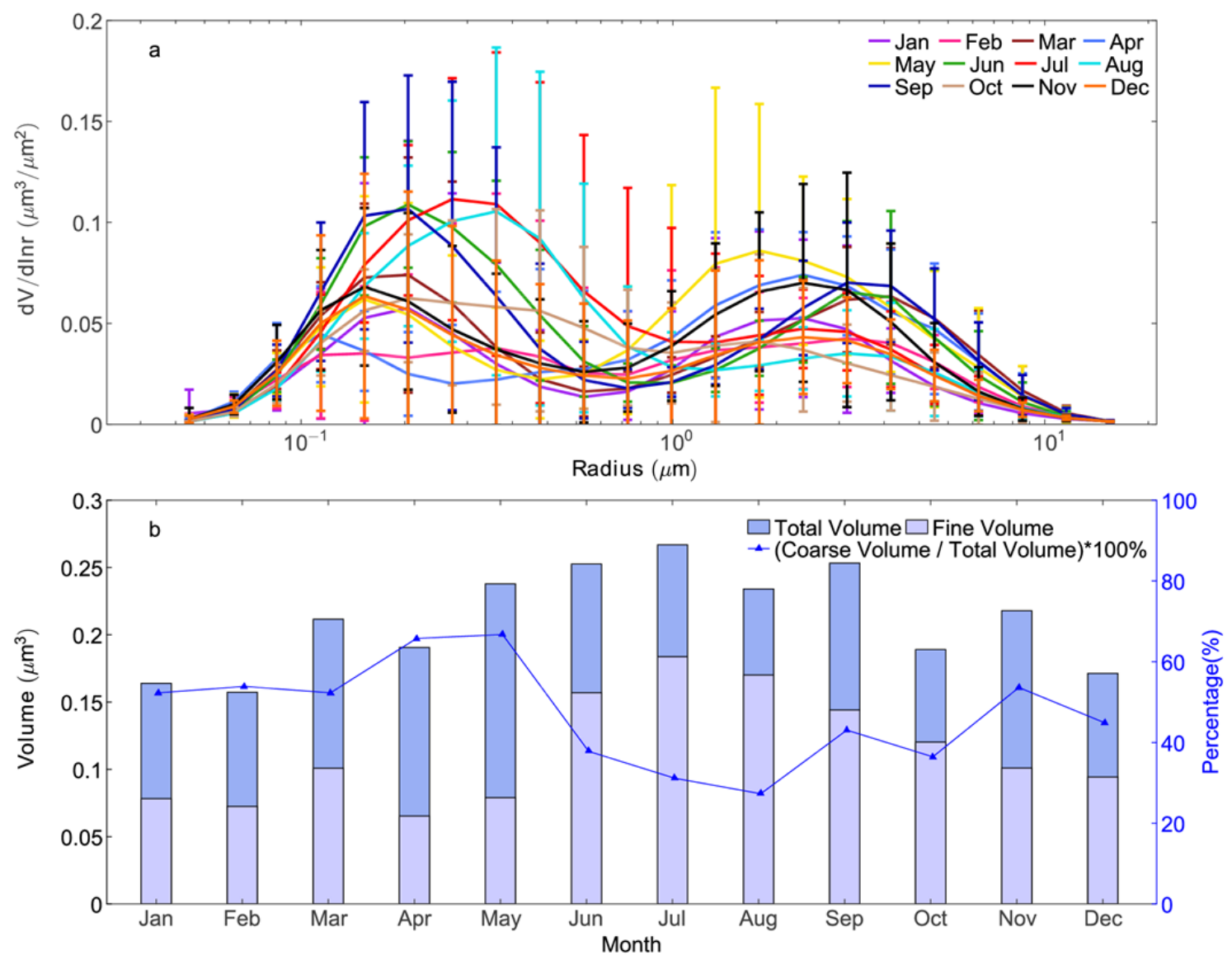

Fig. 2. Monthly variation of (a) aerosol size distribution and (b) aerosol volumes at Jiaozuo-HPU.

(0.75) (Zhao et al., 2015). The annual average $\mathrm{AE}_{440-870 \mathrm{~nm}}$ was $1.12 \pm 0.17$, suggesting that the main particles in the Jiaozuo area were fine-mode particles.

The temporal variations of monthly average $\mathrm{AOD}_{440 \mathrm{~nm}}$, $\mathrm{AE}_{440-870 \mathrm{~nm}}$, and water vapor content (WVC) are shown in Fig. 3. As shown in Fig. 3(a), the monthly variation of AOD was significant. The maximum value of AOD was in July, at $1.11 \pm 0.59$. The AOD in June, August and September was also relatively high, at $0.98 \pm 0.42,0.96 \pm$ 0.52 and $1.07 \pm 0.72$, respectively. The minimum value of AOD was $0.57 \pm 0.41$, in April. The monthly average WVC showed an almost parabolic variation similar to Yangtze River Basin reported by $\mathrm{He}$ et al. (2017), with high values in June to September and the maximum value $(4.71 \mathrm{~cm})$ in July and August (Fig. 3(c)) due to more precipitation. The high AOD values may have been related to the high WVC in these months. As Eck et al. (2005) pointed out, a high WVC in the atmosphere in summer is conducive to the hygroscopic growth of fine particles. Therefore, the hygroscopic effect of fine particles may have caused high levels of extinction in June to September. Besides, the high AOD in June and September may also have been affected by the burning of crop straw. From Fig. 3(b), the monthly mean AE values were all greater than 0.8 , indicating the Jiaozuo area was dominated by finemode aerosol during this period. The maximum monthly AE occurred in June $(1.37 \pm 0.15)$ and the minimum in
April $(0.81 \pm 0.37)$, which is consistent with the analysis of aerosol microphysical characteristics mentioned above.

Additionally, there were clear seasonal variations of $\mathrm{AOD}$ and $\mathrm{AE}$. The mean values of $\mathrm{AOD}_{440 \mathrm{~nm}}$ in four seasons were $0.69 \pm 0.41,1.02 \pm 0.53,0.88 \pm 0.54$ and $0.72 \pm 0.61$, respectively. The maximum AOD occurring in summer was likely related to the combined effect of several factors. Firstly, high relative humidity in summer can cause an increase in AOD (Deng et al., 2012). Secondly, the combustion of straw will produce additional aerosol particles. And thirdly, secondary organic aerosol particles can be generated by photochemical reactions under high temperatures in summer (Kroll and Seinfeld, 2008). Compared with autumn (September-November), the AOD in winter (December-February) was lower, possibly associated with governmental efforts to treat air pollution at that time of year. The seasonal average values of AE were $0.92 \pm$ $0.35,1.27 \pm 0.22,1.09 \pm 0.25$ and $0.98 \pm 0.32$, respectively. The AE in spring was lower than in the other seasons, indicating there were more coarse-mode particles in the atmosphere during that season. In summer, abundant precipitation can eliminate coarse-mode particles via wet deposition, meaning the fine-mode particles begin to dominate. There was a lower AE in winter compared with the background site at Songshan Mountain (1.23). This may be explained by higher levels of fugitive dust in the city (Che et al., 2014). 

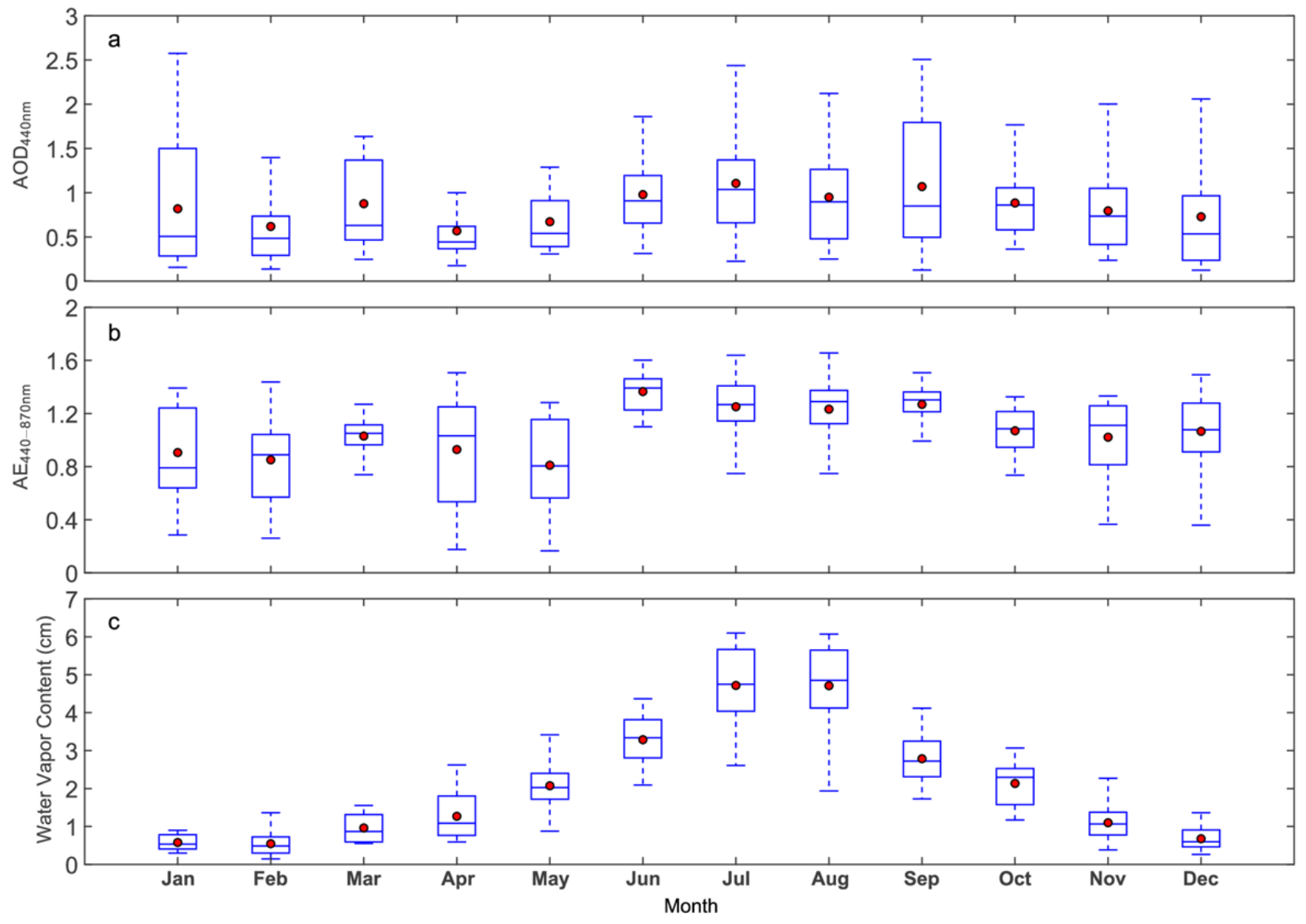

Fig. 3. Monthly variations of (a) $\mathrm{AOD}_{440 \mathrm{~nm}}$, (b) $\mathrm{AE}_{440-870 \mathrm{~nm}}$ and (c) water vapor content (WVC) at Jiaozuo-HPU. The boxes represent the $25^{\text {th }}$ to $75^{\text {th }}$ percentiles of the distributions while the middle line and red dots indicate the means and medians, respectively.

\section{Single Scattering Albedo}

The SSA is an important optical parameter that characterizes the scattering ability of aerosol, which is the proportion of scattering AOD to total AOD. It is mainly determined by the size and composition of aerosol particles (Dubovik et al., 2002). As shown in Fig. 4, there were distinct month-to-month variations of SSA at different wavelengths (440, 670, 870, and $1020 \mathrm{~nm})$. From February to May, the SSA presents a decreasing trend, reaching a minimum in May, with values of $0.86,0.87,0.85$, and 0.84 in the four bands, respectively. This tendency reveals the increasing absorptivity of aerosol particles. The SSA increased sharply from May to August and then declined. The seasonal mean values for SSA at $440 \mathrm{~nm}$ were $0.87 \pm$ $0.05,0.95 \pm 0.04,0.92 \pm 0.05$, and $0.90 \pm 0.04$ for spring, summer, autumn and winter, respectively. The minimal SSA in spring, especially in May, implies light-absorbing dust particles in the atmosphere. The maximum SSA in summer can be attributed to hygroscopic growth under high relative humidity, wherein the size of aerosol particles can modify the spectral properties of the SSA, resulting in an increase in its scattering ability (Xia et al., 2007). Meanwhile, the larger difference between the four wavelengths may imply that hygroscopic aerosol particles are more sensitive to wavelength variation. Compared with summer, a slight decrease in autumn was observed, which can be explained by light-absorbing carbonaceous aerosols from biomass burning (Arola et al., 2011). Thereafter, in winter, the greater concentrations of black carbon aerosol particles in the atmosphere generated by domestic heating emissions may be responsible for the relatively lower SSA values in that season. An interesting phenomenon is that the SSAs at $670 \mathrm{~nm}, 870 \mathrm{~nm}$ and $1020 \mathrm{~nm}$ differed little between autumn and winter, which might be indicative of the SSA being insensitive to wavelength variation within $670-1020 \mathrm{~nm}$ because of the presence of carbonaceous aerosols.

\section{Absorption Aerosol Optical Depth and Absorption Angström Exponent}

The AAOD represents the extent of the absorptive extinction of aerosol particles. Fig. 5(a) plots the monthly variation in AAOD at $440 \mathrm{~nm}$. It shows that the maximum value $(0.084 \pm 0.018)$ of the monthly mean was reached in May and the minimum $(0.038 \pm 0.021)$ in August. The seasonal averages were $0.079 \pm 0.019,0.045 \pm 0.021$, $0.060 \pm 0.029$, and $0.066 \pm 0.036$ for spring, summer, autumn and winter, respectively. A high AAOD value generally reflects the absorption properties of carbonaceous aerosols and dust aerosols (Torres et al., 2005). The 


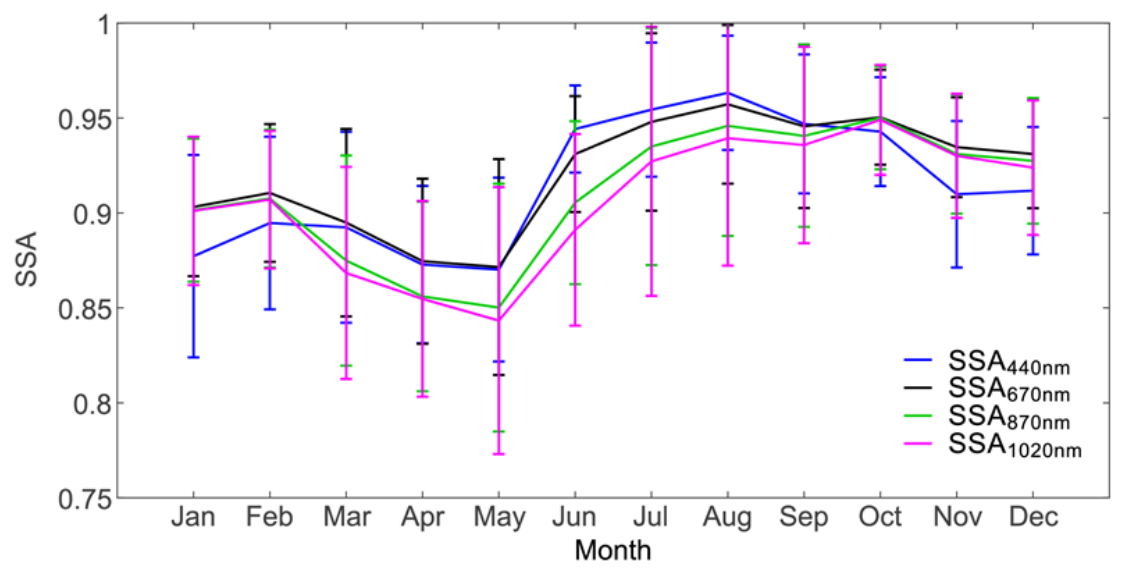

Fig. 4. Monthly variations of single scattering albedo (SSA) at 440, 670, 870, and $1020 \mathrm{~nm}$ at Jiaozuo-HPU.
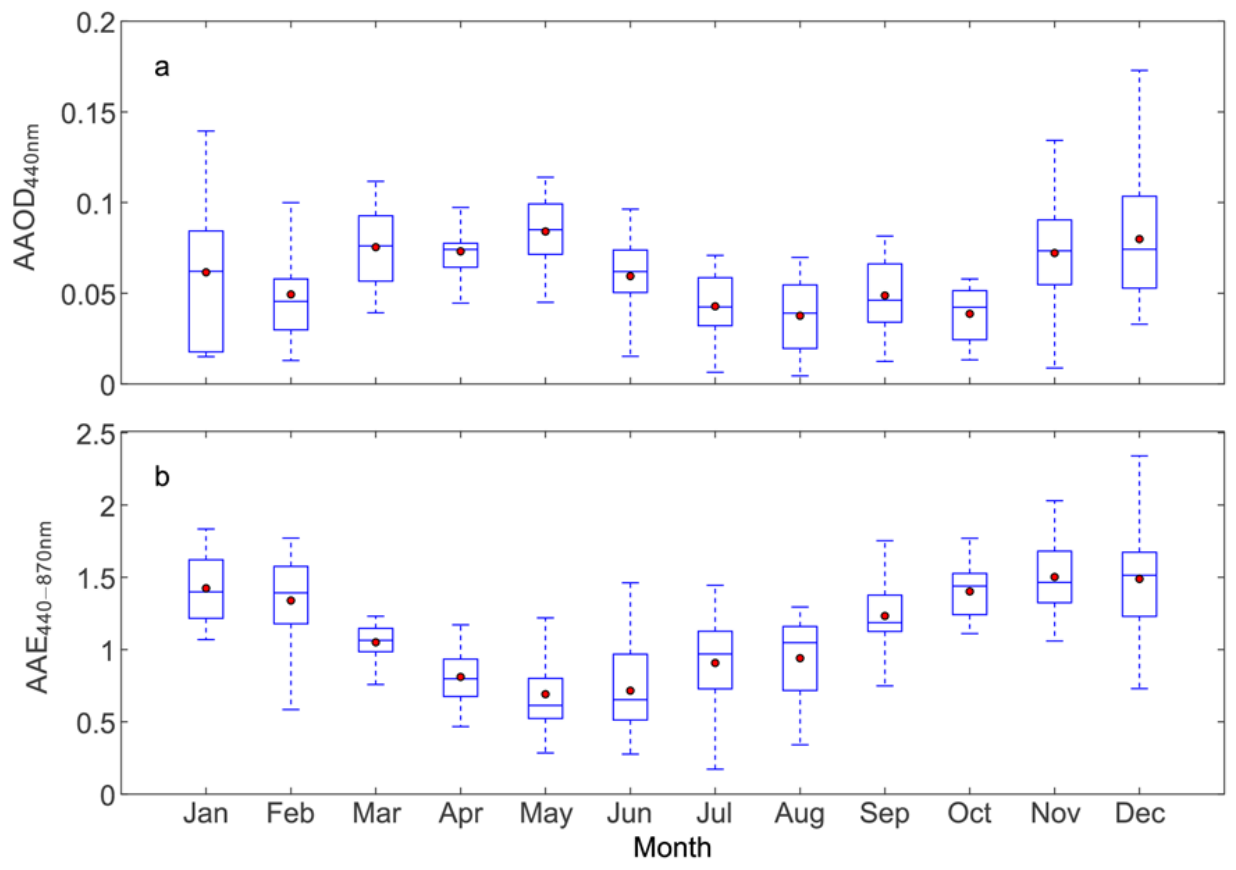

Fig. 5. Monthly variations of (a) $\mathrm{AAOD}_{440 \mathrm{~nm}}$ and (b) $\mathrm{AAE}_{440-870 \mathrm{~nm}}$ at Jiaozuo-HPU. See Fig. 3 for an explanation of the symbols.

maximum value of AAOD being in spring reflected the strongest absorption ability occurring in that season because of the long-range transportation of absorptive dust particles from surrounding and remote areas of northwestern China. It is worth noting that the AAOD reaching its maximum in spring was accompanied by the minimum SSA, followed by a significant drop when entering the summer season. As a result, the AAOD in summer was at a minimum, suggestive of high concentrations of light-scattering particles. Such a pattern in summer may be associated with the wet deposition of dust particles in the rainy season. Besides, another reasonable explanation for low AAOD is increasing concentrations of secondary aerosols, such as nitrates and sulfates, from different sources (e.g., industrial emissions, photochemical reactions, vehicle exhaust). After summer, the occurrence of black carbon aerosol particles generated by straw combustion in early autumn, as well as the rise in domestic heating later that season, were likely responsible for the increased AAOD in September and November, respectively. As for winter, the AAOD was higher than the values $(<0.05)$ previously observed in Hangzhou (Che et al., 2018) and Hefei (Liu et al., 2017), but lower than that (0.1) in Shenyang (Zhao et al., 2015). The use of coal for heating purposes produces substantial amounts of absorbing black carbon aerosols in the Jiaozuo area. The same is true of Shenyang; plus, more absorbing particles generated by heavy industry in Shenyang and its surrounding areas contribute there to its high AAOD values. Relatively lower values appear in winter in southern China (e.g., in Hangzhou and Hefei), owing to comparatively low emissions of absorptive particles from domestic heating.

The types of absorbing aerosol particles (e.g., black carbon, organic matter, and dust) can be distinguished 
based on the AAE (Giles et al., 2012). Fig. 5(b) shows the monthly variations of AAE. From April to August, the monthly mean AAE was generally lower than 1 . The occurrence of black carbon coated with absorbing or nonabsorbing materials has been cited as a possible cause of the AAE being far lower than 1 (Bergstrom et al., 2007; Gyawali et al., 2009). However, it might also be related to measurement uncertainties and/or errors in retrieving the SSA (Dubovik and King, 2000). Thus, more observations are needed in the future to confirm these apparently low AAE values. The average AAE was relatively high $(>1)$ in the colder months of September to March. Indeed, from the perspective of seasonal variation, the AAE was significantly higher in autumn $(1.41 \pm 0.26)$ and winter $(1.49 \pm 0.36)$ than in spring $(0.87 \pm 0.25)$ and summer $(0.89 \pm 0.30)$. The AAE values in autumn and winter exceeded 1.10, indicating an obvious increase in organic aerosol concentrations from biomass burning and mineral dust (Lack and Cappa, 2010; Russell et al., 2010). Looking at the year as a whole, the annual mean AAE value was $1.09 \pm 0.41$, which is close to 1 , possibly indicative of the absorbing aerosols in the Jiaozuo region being primarily composed of black carbon produced by fossil fuel combustion (Bergstrom et al., 2007).

\section{Aerosol Type Classification}

Aerosols originating from different sources have a diverse range of atmospheric effects (Dubovik et al., 2002; Alam et al., 2016); hence, it is essential in any study like the present one to identify the types of aerosols observed. The most commonly used classification technique is correlating the AOD with the AE and then classifying the aerosols into "dust," "anthropogenic" or "marine." However, this approach is incapable of sorting aerosols into "absorbing" or "non-absorbing" (Lee et al., 2010; Xia et al., 2016). The absorptivity of aerosol has a substantial effect on the process of direct radiative forcing (IPCC, 2013), which plays a crucial role in quantifying the influence of aerosols on Earth's climate. It is, however, possibly to distinguish between absorbing and nonabsorbing aerosols based on their SSA values (Lee et al., 2010). In addition, the fine-mode fraction (FMF), which is defined by $\mathrm{AOD}_{\text {fine }(440 \mathrm{~nm})} / \mathrm{AOD}_{440 \mathrm{~nm}}$, and the $\mathrm{AE}$, can be used to characterize the dominant size mode of aerosols. In this work, aerosol optical parameters (FMF, SSA and AE) from the Jiaozuo-HPU site were used to classify aerosols into eight types following the method described in Zheng et al. (2017) and Che et al. (2018). Table 2 summarizes the
SSA and AE threshold values for the eight types.

The aerosol types and their proportions in the Jiaozuo area are illustrated in Figs. 6 and 7, respectively. From Figs. 6(a) and 7(a), we can see that the aerosols were dominated by absorbing fine particles (Type I, II, III) and mixed absorbing particles (Type V), accounting for $36.89 \%$ and $35.35 \%$, respectively. This indicates that high emissions of absorbing fine-mode aerosols, such as carbonaceous aerosols from agricultural and industrial activities, existed in Jiaozuo. The non-absorbing fine particles (Type IV) accounted for $10.85 \%$, with a value of 0.91 for the FMF, suggesting the presence of some sulfate and nitrate aerosols from the burning of fossil fuel. The proportion of mixed non-absorbing particles (Type VI) was $10.42 \%$, which was slightly lower than the Type IV proportion, and the FMF almost exceeded 0.9. The nonabsorbing coarse particles (Type VIII) showed a negligible percentage of total aerosol $(0.51 \%)$, which might have been associated with the region being far away from the sea. Additionally, a significant seasonal difference in aerosol types is apparent from Figs. 6(b)-6(e) and Figs. 7(b)-7(e). The absorbing coarse particles (mainly dust) (Type VII) accounted for $15.12 \%, 0 \%, 4.46 \%$ and $6 \%$ in the four seasons, respectively, and the FMF varied from 0.44 to 0.52 . The highest percentage of dust being in spring was mainly related to the long-range transport activities of that season (Yan et al., 2015), whereas dust particles were almost eliminated in summer because of heavy rainfall. Owing to the existence of more nitrate and sulfate being produced by high-intensity human activity and/or photochemical reactions under high temperatures (Hennigan et al., 2008), the percentage of Type IV was higher in summer than in other seasons, at 20.87\% (FMF: 0.96). The absorbing finemode aerosols (Type I, II, III), as the highest proportion in Jiaozuo, accounted for $34.15 \%, 29.13 \%, 39.88 \%$, and $40.25 \%$ in spring, summer, autumn and winter, respectively, and the FMF values of these particles varied from 0.86 to 0.93 .

\section{Relationship between AOD and Meteorological Conditions}

The accumulation and diffusion of aerosols are both influenced considerably by meteorological factors (Che et al., 2014; Wang et al., 2018). In this next part of our study, we examined the relationship between two such meteorological factors (namely, relative humidity and wind speed) and AOD. Figs. 8(a) and 8(b) show the variation

Table 2. Threshold values of aerosol properties for different absorbing types of aerosol.

\begin{tabular}{llll}
\hline Group & Aerosol type & AE & SSA \\
\hline Type I & Fine highly-absorbing & $>1.2$ & $\leq 0.85$ \\
Type II & Fine moderately-absorbing & $>1.2$ & $\geq 0.85$ and $<0.9$ \\
Type III & Fine slightly absorbing & $>1.2$ & $\geq 0.9$ and $<0.95$ \\
Type IV & Fine non-absorbing & $>1.2$ & $>0.95$ \\
Type V & Mixed absorbing & $\geq 0.6$ and $<1.2$ & $\leq 0.95$ \\
Type VI & Mixed non-absorbing & $\leq 1.2$ & $>0.95$ \\
Type VII & Coarse absorbing & $\leq 1.2$ & $\leq 0.95$ \\
Type VIII & Coarse non-absorbing & & $>0.95$ \\
\hline
\end{tabular}



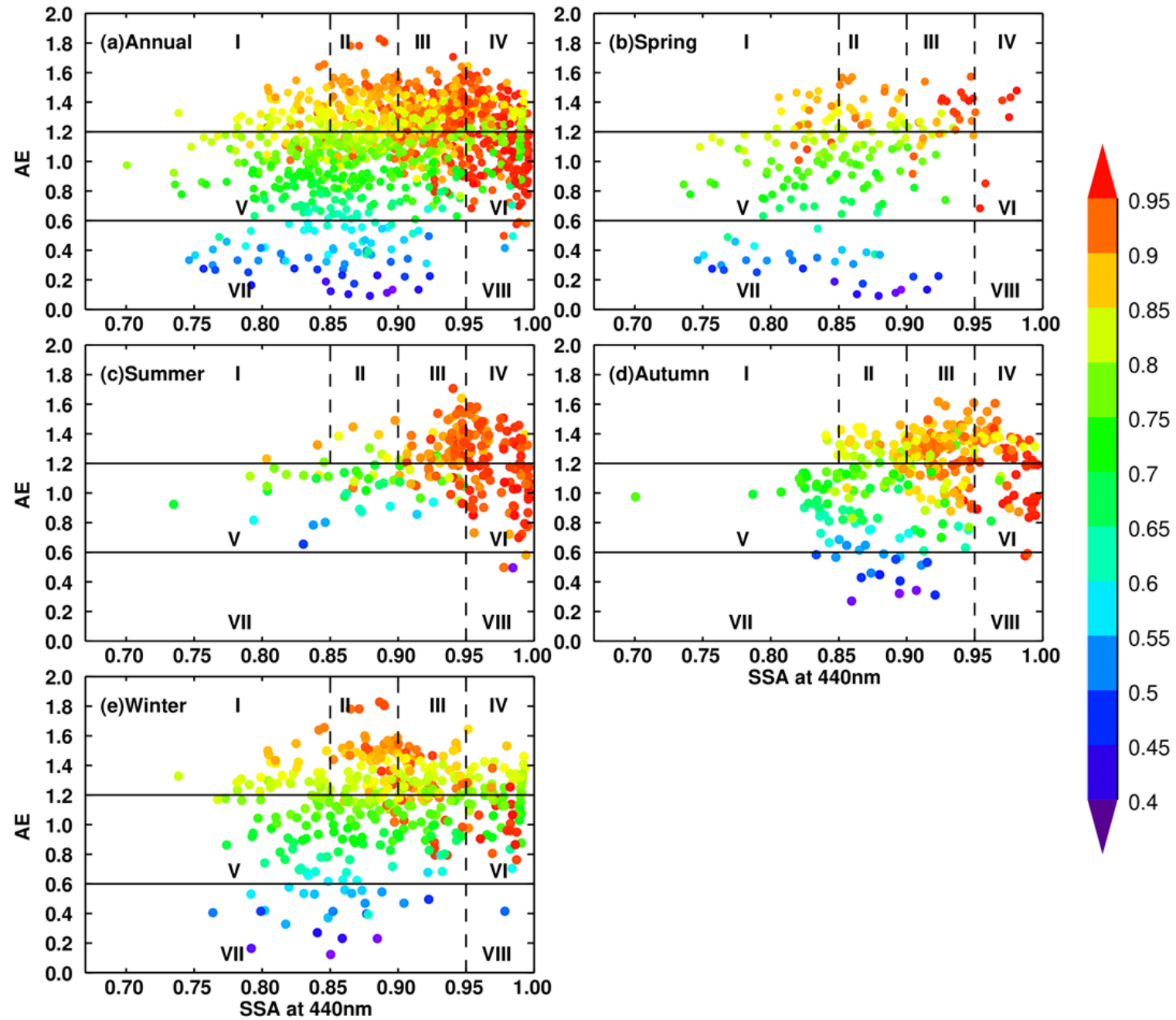

Fig. 6. The aerosol type classification using SSA, AE and FMF data for (a) annual, (b) spring, (c) summer, (d) autumn, and (e) winter. See text in Table 2 for description of Groups I-VIII.

trends of AOD as a function of relative humidity and wind speed, respectively. Clearly, relative humidity and wind speed have opposite effects on aerosol particles. Fig. 8(a) shows that AOD increased with relative humidity, and was only $0.30 \pm 0.17$ in the range of $0-20 \%$. However, the AOD rose to $1.18 \pm 0.55$, reaching a maximum, when the relative humidity was greater than $70 \%$. These results indicate that relative humidity has a significant effect on the hygroscopic growth of fine hydrophilic particles (Gui et al., 2016; Zhang et al., 2017b). Besides, Hennigan et al. (2008) reported that secondary aerosol particles, such as $\mathrm{NO}_{3}{ }^{-}$and $\mathrm{SO}_{4}{ }^{2-}$, as well as other secondary organic compounds, form easily in conditions of high relative humidity, which is analogous to the situation in cloud processing. As shown in Fig. 8(b), in contrast, there is negative correlation between AOD and wind speed, and AOD showed a gradual declining trend with higher wind speed. When the wind speed was lower than $1 \mathrm{~m} \mathrm{~s}^{-1}$, the AOD was as high as $0.93 \pm 0.57$, whereas the AOD dropped to a low level of $0.49 \pm 0.16$ with the wind speed increasing to 5-6 $\mathrm{m} \mathrm{s}^{-1}$, reflecting the effect of wind on the diffusion of aerosol particles (He et al., 2012b; Gui et al.,
2016; Li et al., 2016). The specific impact of the wind direction on pollutants is discussed below in the context of two pollution processes (haze and dust).

\section{Pollution Source Analysis during Dust and Haze Events}

To further investigate the variation in aerosol optical properties and pollution sources, two typical pollution outbreak processes (haze and dust) that occurred in Jiaozuo during the study period were selected based on their associated news reports, meteorological data and satellite data. The MODIS true color images during the dust and haze episodes are displayed in Fig. 9. Compared with Figs. 9(a) and 9(g), there is a clear haze coverage over Jiaozuo in Figs. 9(b)-9(f). Figs. 9(i) and 9(j) show the presence of dust. In addition, this dust event can be confirmed by the NASA Earth Observatory (https://eartho bservatory.nasa.gov/NaturalHazards/).

Figs. 10(a) and 10(d) depict the 72-h backward trajectories at multiple heights during the haze and dust cases over Jiaozuo. From Fig. 10(a) it can be seen that the trajectories over haze can be grouped into four clusters. Cluster-4, at an altitude below $500 \mathrm{~m}$, contributes the maximum percentage 
(a) Annual $0.51 \%$
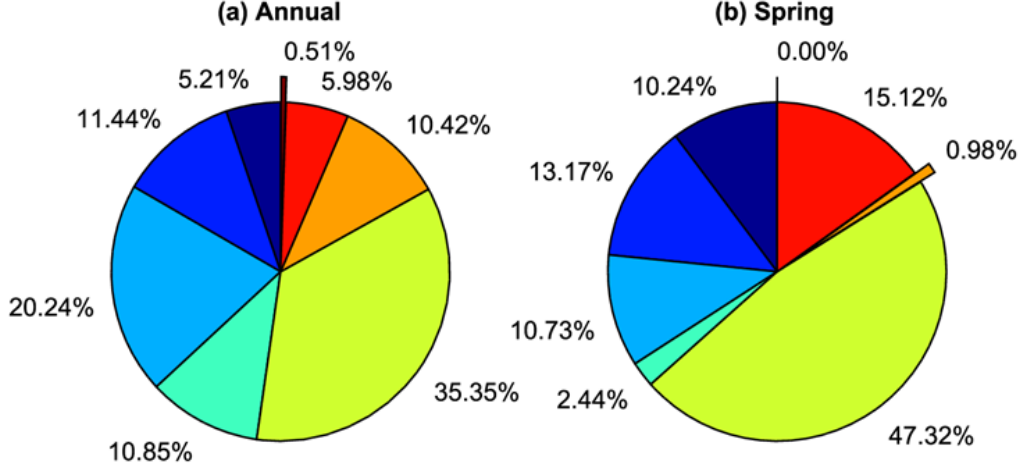

(c) Summer

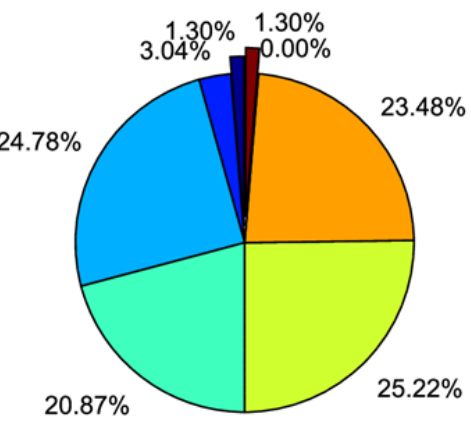

(d) Autumn

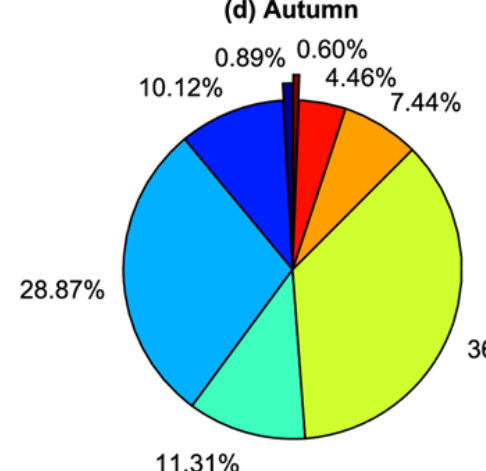

(e) Winter

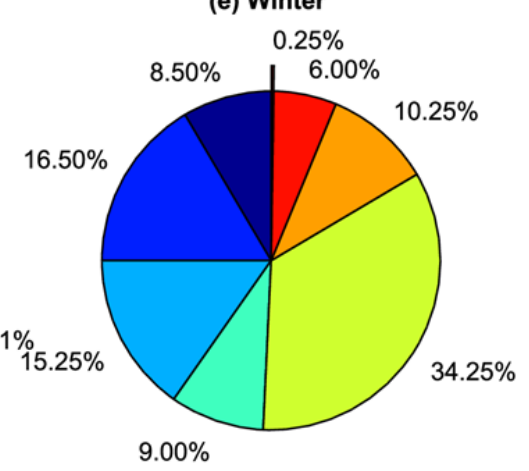

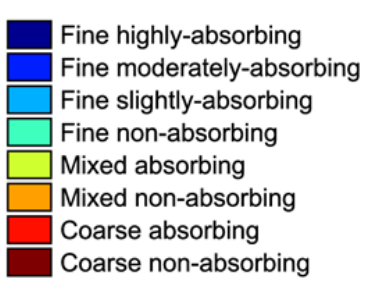

Fine highly-absorbing
Fine moderately-absorbing
Fine slightly-absorbing
Fine non-absorbing
Mixed absorbing
Mixed non-absorbing
Coarse absorbing
Coarse non-absorbing

Fig. 7. The frequency distribution of aerosol types for (a) annual, (b) spring, (c) summer, (d) autumn, and (e) winter. See text in Table 2 for description of Groups I-VIII.
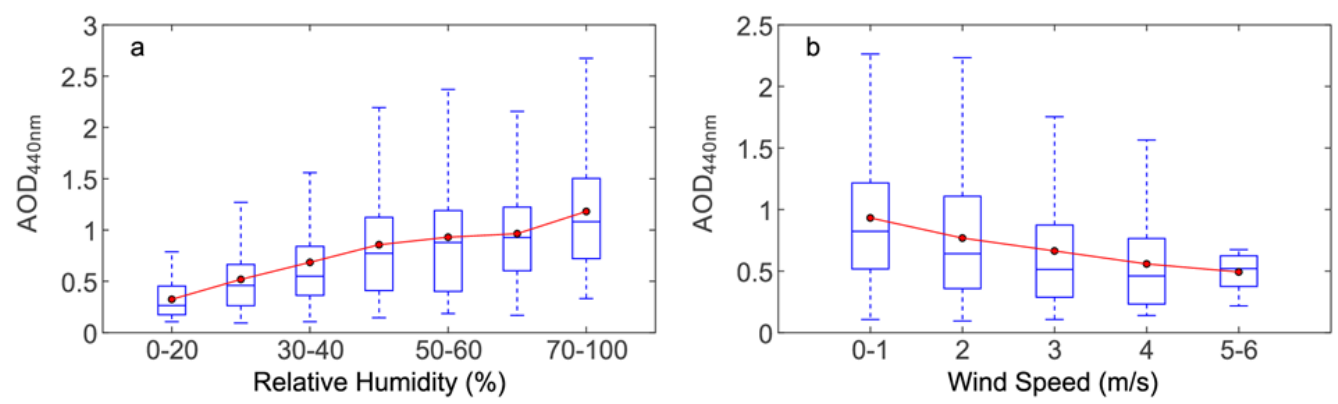

Fig. 8. The correlation between $\mathrm{AOD}_{440 \mathrm{~nm}}$ and (a) relative humidity and (b) wind speed at Jiaozuo-HPU.

of $38.89 \%$, which is from the northern part of Anhui Province. Cluster-2 accounts for $31.48 \%$ and originates from southern Shaanxi, passing over northern Shaanxi and southern Shanxi and then to Jiaozuo. The air masses associated with Cluster-3 originate from north of Xinjiang, at the highest altitude of $4000 \mathrm{~m}$, accounting for the minimum proportion of $5.56 \%$. Similar to Cluster-2, Cluster-3 also arrives via southern Shanxi. Cluster-1 originates from the border area between the provinces of Henan, Shandong and Hebei, at an altitude below $500 \mathrm{~m}$, accounting for $24.07 \%$. As shown in Fig. 10(d), the potential source region is mainly located in the area to the northwest of Jiaozuo during dust episodes. The air mass trajectories originate from an altitude above $4000 \mathrm{~m}$ and then gradually decline to $2000 \mathrm{~m}$, before eventually travelling across the Taihang Mountains to the receptor site in Jiaozuo. Cluster-1 originates from the Gobi Desert lying on the eastern edge of Xinjiang, accounting for $36.11 \%$, and passes over the Badain Juran Desert and Tengger Desert (Inner Mongolia), northern Ningxia Hui Autonomous Region, northern Shaanxi, southern Shanxi, and then on into Jiaozuo. The air masses associated with Cluster-2 have long-range and high-altitude trajectories originating from Russia and travelling over the arid and semi-arid regions of Mongolia (Wang et al., 2006), accounting for $63.89 \%$. When the air masses enter China, they passed over the Ulan Buh Desert, the Mu Us Desert, and southern Shanxi, before reaching Jiaozuo. Hence, Cluster-2 has a sizeable effect on $\mathrm{PM}_{10}$ concentrations in Jiaozuo. 


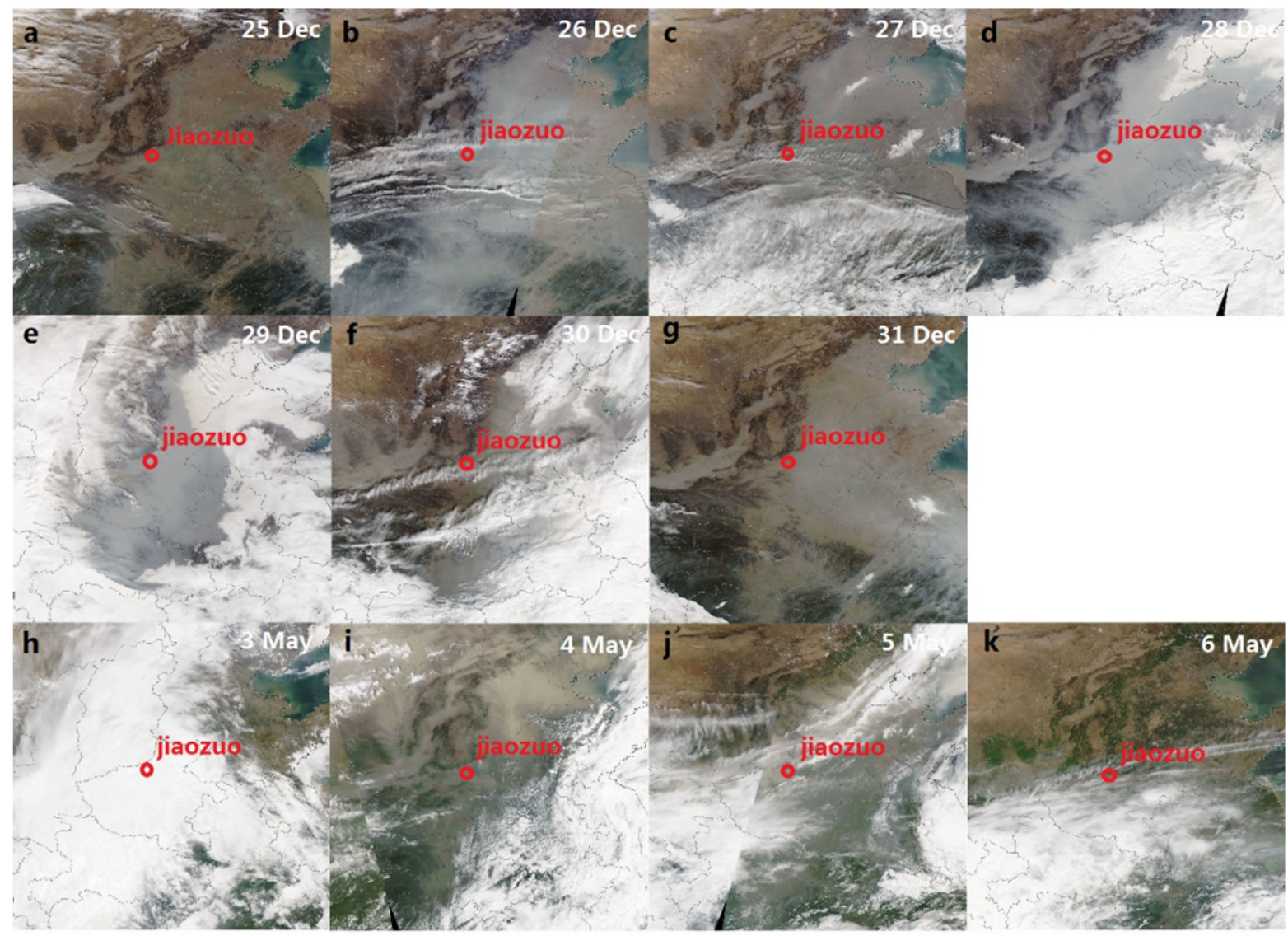

Fig. 9. MODIS Terra true color images during haze $(\mathrm{a}-\mathrm{g})$ and dust $(\mathrm{h}-\mathrm{k})$ events.

Figs. 10(b) and 10(c) show the results from the WPSCF and WCWT analyses for a haze event that took place from $25 \mathrm{Dec}$ to $31 \mathrm{Dec}$. It is clear that the distributions of WPSCF and WCWT are similar in pattern. In general, the high WPSCF values $(>0.8)$ are mainly located in Henan Province and surrounding areas, including southern Hebei, western Shandong, northern Anhui, northern Shaanxi, and southern Shanxi, which can be regarded as the most likely source areas. Interestingly, Fig. 10(b) shows the WPSCF values in northern Henan Province to have exceeded 0.9, suggesting local emissions contributed greatly to $\mathrm{PM}_{2.5}$ concentrations. Meanwhile, it is apparent from Fig. 10(c) that northern Henan, eastern Henan, southern Shaanxi, northern Anhui, southwestern Inner Mongolia, northern Shaanxi, and southern Shanxi, with rather high WCWT values of around $120 \mu \mathrm{g} \mathrm{m}^{-3}$, seemed to be the areas contributing to the deterioration in air quality in Jiaozuo. Indeed, the long and narrow area from southwestern Inner Mongolia to southern Shanxi is an important coal base in China. The mining, utilization and transportation of coal inevitably leads to serious air pollution problems. Southern Hebei and western Shandong, contiguous to Henan Province, also contributed greatly to the $\mathrm{PM}_{2.5}$ values of $80-120 \mu \mathrm{g} \mathrm{m}^{-3}$. Furthermore, pollutant transport from southern Jiangsu Province (including Shanghai), which is a well-developed region in China with high levels of anthropogenic activity, also increased the accumulation of $\mathrm{PM}_{2.5}$ in Jiaozuo, by 90-120 $\mathrm{g} \mathrm{m}^{-3}$.
The distributions of WPSCF and WCWT values under dust conditions showed significant diversity compared with haze days. Unlike the potential sources of haze mentioned above coming from different directions, the region to the northwest of Jiaozuo contributed almost all of the $\mathrm{PM}_{10}$ concentration under dust. The WPSCF value (Fig. 10(e)) in the western part of Inner Mongolia was about 0.5, which Zhang et al. (1998) termed the "Northern High Dust Desert," including the Badain Juran Desert, the Ulan Buh Desert, and the Hobq Desert. The contribution of the Northern High Dust Desert to the $\mathrm{PM}_{10}$ loadings in Jiaozuo varied from $100-200 \mu \mathrm{g} \mathrm{m}^{-3}$, and was even more than $300 \mu \mathrm{g} \mathrm{m}^{-3}$ in some areas (Fig. 10(f)). Additionally, the arid and semi-arid areas of western Mongolia contributed to the high $\mathrm{PM}_{10}$ in Jiaozuo by $160-250 \mu \mathrm{g} \mathrm{m}^{-3}$. Moreover, what is striking in Figs. 10(e) and 10(f) is that extremely high values of WPSCF $(>0.9)$ and WCWT $\left(>300 \mu \mathrm{g} \mathrm{m}^{-3}\right.$ ) exist in northern Shaanxi and southern Shanxi Province, suggesting these areas contributed the most $\mathrm{PM}_{10}$. On the one hand, the air masses associated with Cluster-1 and Cluster-2 flowed together in Shaanxi and Shanxi; on the other hand, this area was a dust source owing to its location in the eastern part of the Loess Plateau.

The atmospheric vertical information including the $532 \mathrm{~nm}$ total attenuated backscatter (top), the volume depolarization ratio (middle), and aerosol subtype (bottom) provided by CALIPSO data for the dust event is shown in Fig. 11. Volume depolarization ratio (VDR) can distinguish 

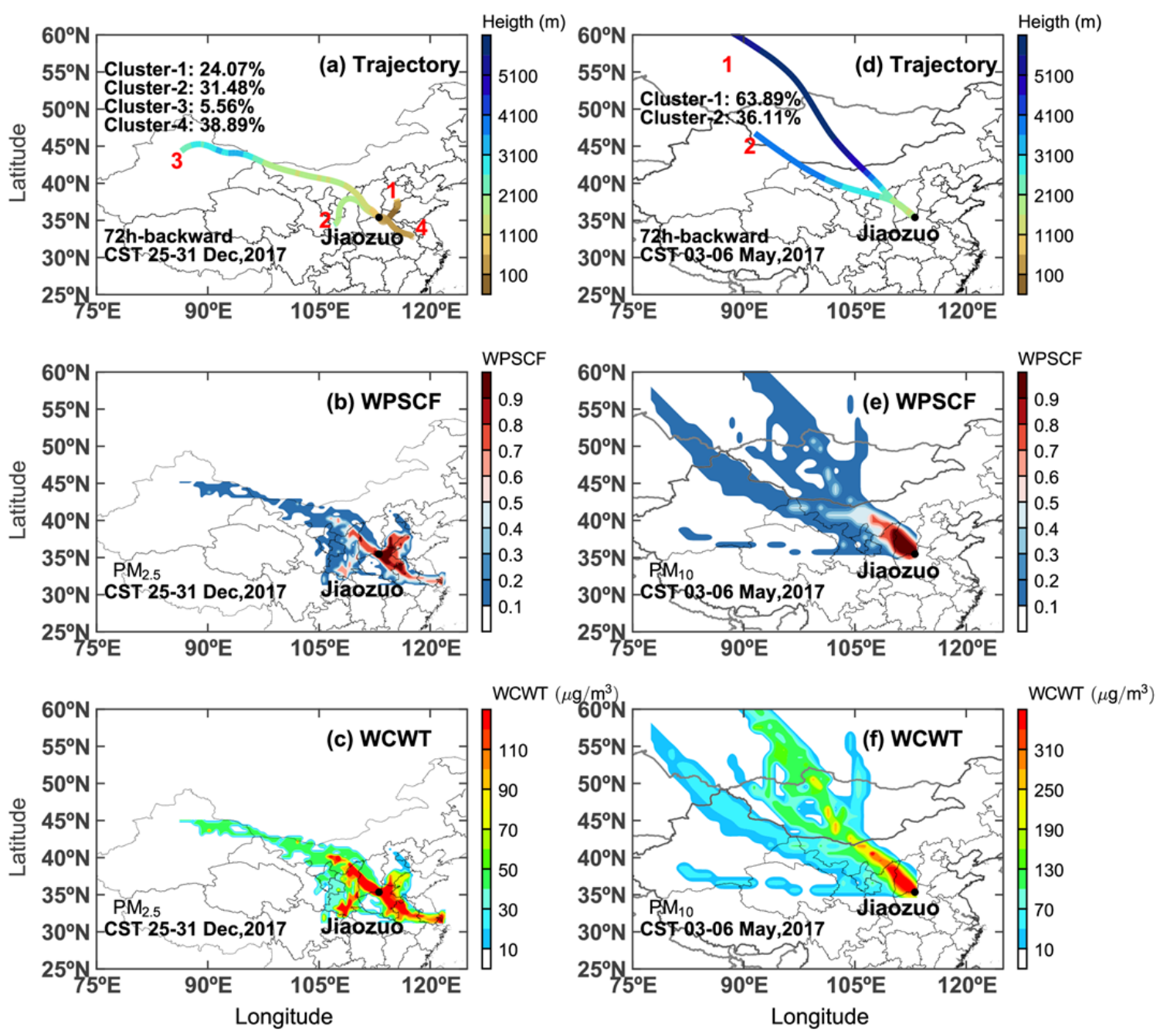

Fig. 10. The 72-h backward trajectories and the results of WPSCF and WCWT analysis during haze (a, b, c) and dust (d, e, f) events.

dust and anthropogenic aerosols (Liu et al., 2008; Tao et al., 2014), and aerosol subtypes include clean marine, dust, polluted and clean continental, polluted dust, and smoke (Omar et al., 2009; Liu et al., 2017). On 3 May and 4 May, the satellite swept across Shaanxi Province and Inner Mongolia. The VDR values $(>0.2)$ indicated that the particles are predominantly non-spherical (dust) on 4 May. The CALIPSO vertical detections showed that dust particles were concentrated at the height of $2-4 \mathrm{~km}$ in the middle atmospheric layer. The satellite was across northwestern Henan Province on 5 May, and the height of dust particles has declined according to the aerosol subtype. These airborne dust may follow the air mass in Fig. 10(d) to the Jiaozuo area. On 6 May, the VDR values $(>0.2)$ were concentrated in upper part of the aerosol layer and dropped to less than $1 \mathrm{~km}$. The aerosol subtype results also confirmed that the dust particles deposited in Jiaozuo and downstream areas.

\section{Aerosol Optical Properties under Dust and Haze Events}

Before analyzing the aerosol optical properties during haze and dust events, we investigated the temporal variation of meteorological elements (the wind field) and PM concentrations, both of which contribute to the overall air pollution situation. As Fu et al. (2014) demonstrated, the wind direction can affect the transportation of pollution and determine the spatial distribution of atmospheric pollutants.

Figs. 12(a) and 13(a) show the wind field at the surface along with the daily mean $\mathrm{PM}_{2.5}$ and $\mathrm{PM}_{10}$ concentrations during the entirety of the haze process that occurred from 25 Dec to 31 Dec. The $\mathrm{PM}_{2.5}$ and $\mathrm{PM}_{10}$ concentrations on 25 Dec, the day before the haze "explosion," were at relatively low levels of $49 \mu \mathrm{g} \mathrm{m}^{-3}$ and $114 \mu \mathrm{g} \mathrm{m}^{-3}$, respectivelylevels that were lower than China's National Ambient Air Quality Standards $\left(75 \mu \mathrm{g} \mathrm{m}^{-3}\right.$ for $\mathrm{PM}_{2.5}$ and $150 \mu \mathrm{g} \mathrm{m}^{-3}$ for $\mathrm{PM}_{10}$; GB3095-2012, http://kjs.mep.gov.cn/hjbhbz/bzwb/dq hjbh/dqhjzlbz/201203/t20120302_224165.htm) and therefore suggestive of good air quality in Jiaozuo. This may have been the result of strong southwesterly wind on that day $\left(>3 \mathrm{~m} \mathrm{~s}^{-1}\right.$ ), which was consistent with the direction of the Taihang Mountains being unfavorable for the accumulation of pollutants. The pollutants from eastern Henan and western Shandong were brought to Jiaozuo by easterly 


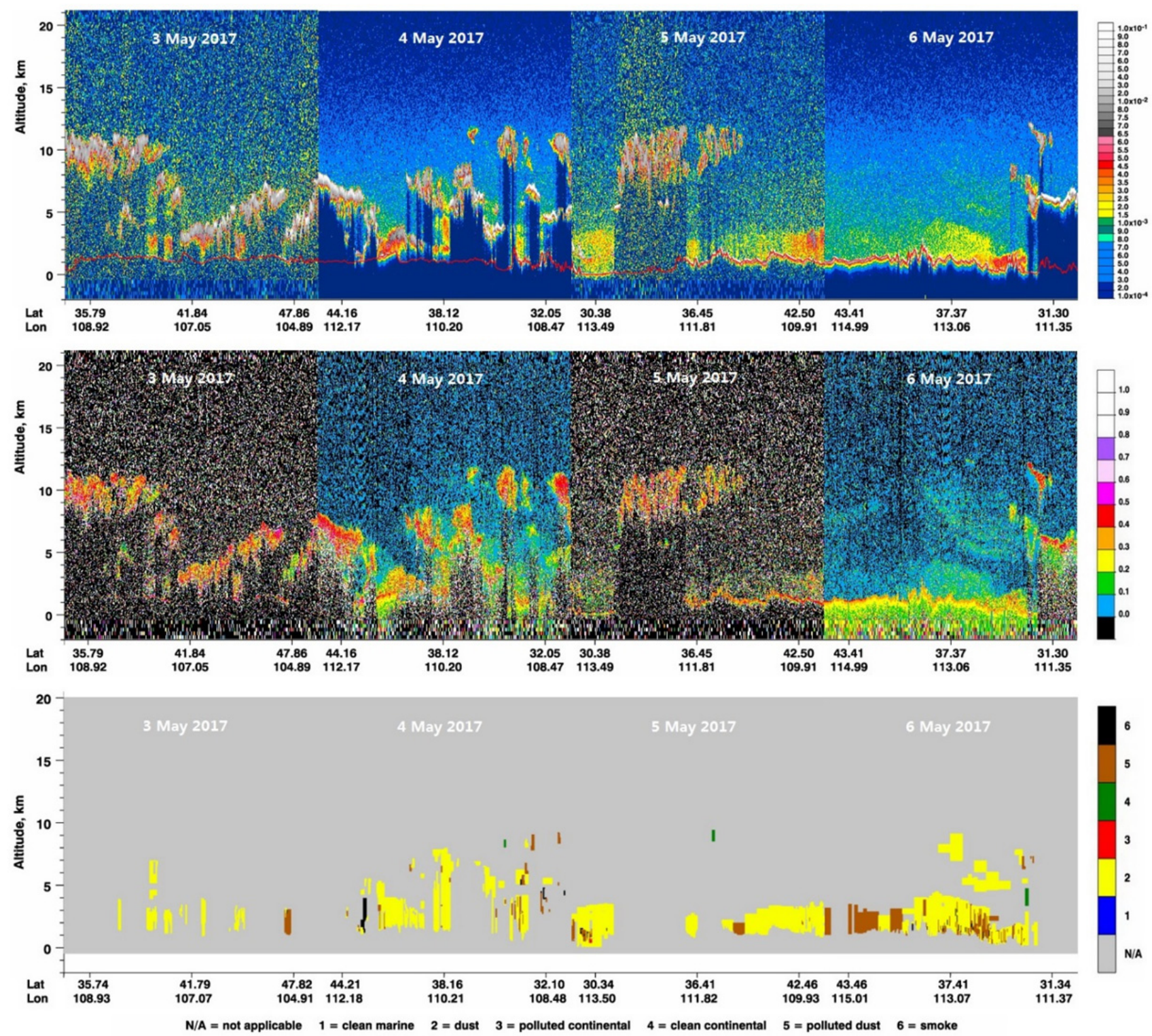

Fig. 11. CALIPSO total attenuated backscatter at $532 \mathrm{~nm}$ (top), volume depolarization ratio (middle), and aerosol subtype (bottom) on the daytime of 3 and 5 May and the nighttime of 4 and 6 May.

wind and southeasterly wind with high speeds $\left(>2 \mathrm{~m} \mathrm{~s}^{-1}\right)$ during the development stage of the haze on 26 and 27 Dec. Pollutants gradually accumulated, resulting in an increase in $\mathrm{PM}_{2.5}$ and $\mathrm{PM}_{10}$ concentrations. This suggests that the haze in the Jiaozuo area was affected not only by local emissions but also by transmission from other areas. Afterwards, the wind speed decreased to below $1 \mathrm{~m} \mathrm{~s}^{-1}$ and the $\mathrm{PM}_{2.5}$ concentration increased rapidly to $205 \mu \mathrm{g} \mathrm{m}^{-3}$ on 28 Dec. On 29 Dec, the $\mathrm{PM}_{2.5}$ and $\mathrm{PM}_{10}$ concentrations continued to rise, reaching peak values of $245 \mu \mathrm{g} \mathrm{m}^{-3}$ and $340 \mu \mathrm{g} \mathrm{m}^{-3}$, respectively. Thereafter, the wind direction turned northwesterly with increasing wind speed $\left(>4 \mathrm{~m} \mathrm{~s}^{-1}\right)$, creating favorable conditions for the dissipation of pollution. Consequently, the concentration of $\mathrm{PM}_{2.5}$ slumped to $94 \mu \mathrm{g} \mathrm{m}^{-3}$ on $30 \mathrm{Dec}$. The decline continued on $31 \mathrm{Dec}$ and the concentrations of $\mathrm{PM}_{2.5}$ and $\mathrm{PM}_{10}$ fell to within desirable air quality standards, signalling a complete end to the haze episode.

The daily wind fields at $750 \mathrm{hPa}$ (height of $3000 \mathrm{~m}$ above ground level) from ERA-Interim (Fig. 12(b)) during a dust event that occurred in May demonstrate how the pollutants from northeastern China were transported to the Jiaozuo area. Northwesterly winds with high speeds $\left(>14 \mathrm{~m} \mathrm{~s}^{-1}\right)$ prevailed over northeastern China during this dust event, creating conditions for the transportation of dust. However, strong southeasterly wind was dominant in the Jiaozuo region on 3 May, meaning coarse particles did not arrive and there was low $\mathrm{PM}_{10}\left(67 \mu \mathrm{g} \mathrm{m}^{-3}\right)$ that day (Fig. 13(b). The next day, however, the wind direction at $750 \mathrm{hPa}$ changed from southeasterly to northerly and the wind speed increased to $16 \mathrm{~m} \mathrm{~s}^{-1}$, contributing to the accumulation of $\mathrm{PM}_{10}$ mass concentration by $219 \mu \mathrm{g} \mathrm{m}^{-3}$. The wind speed gradually declined, which was conducive to the formation of stable conditions on 5 Mar, resulting in the highest $\mathrm{PM}_{10}$ 
a
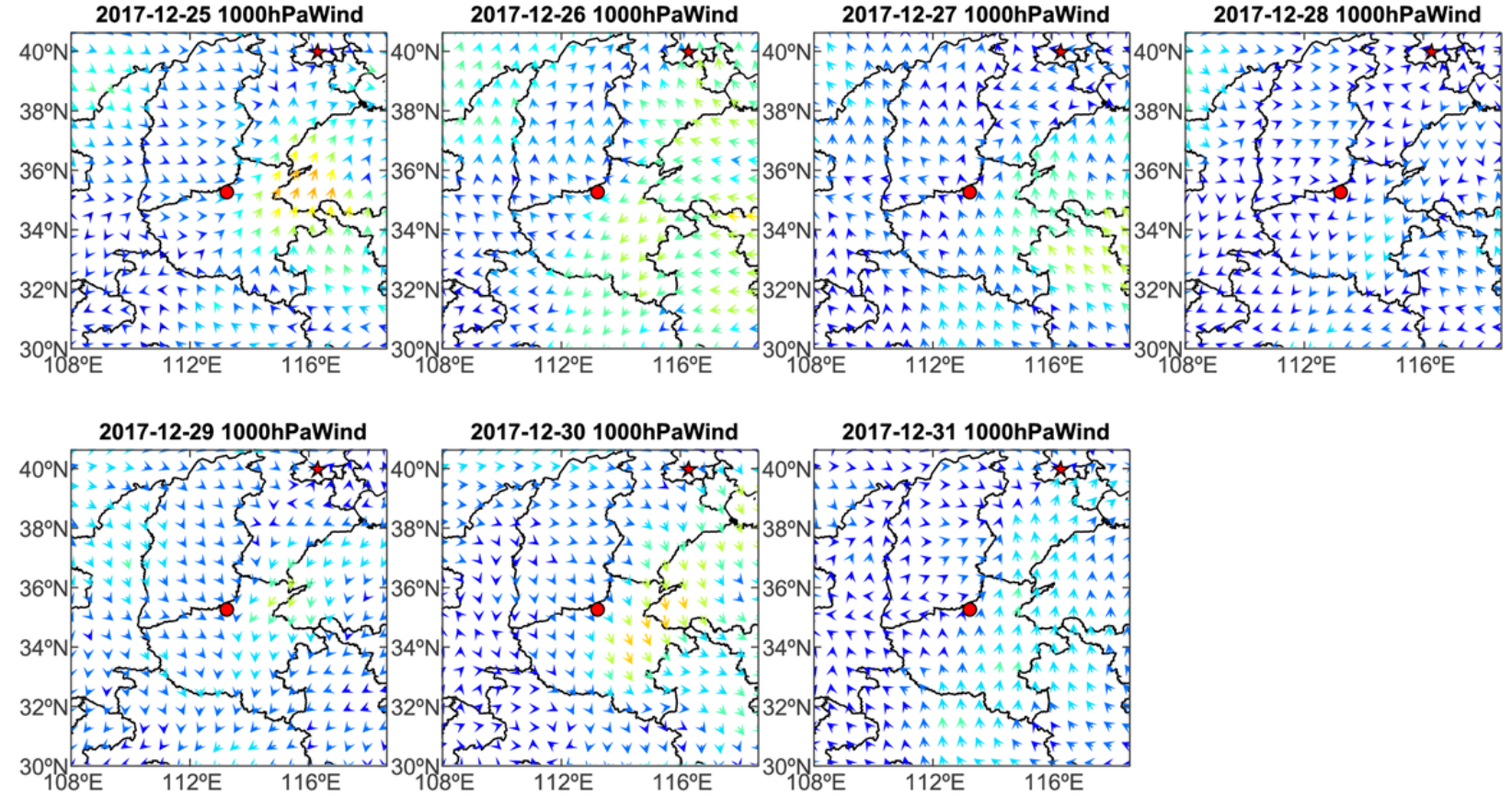

b

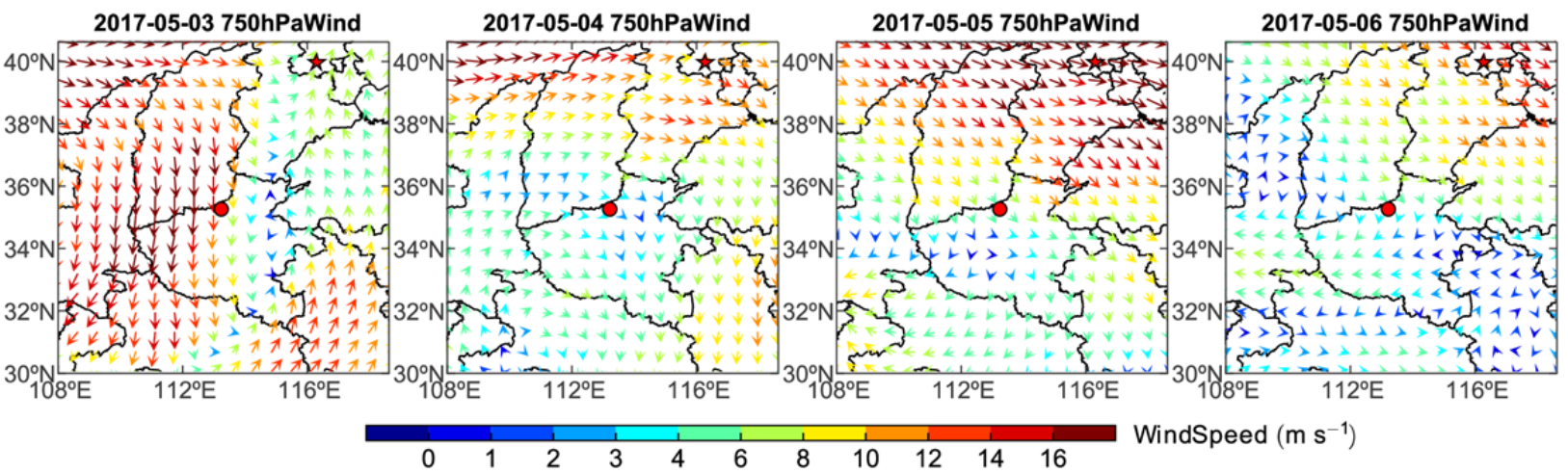

Fig. 12. Daily average wind fields at (a) the surface during haze and (b) $750 \mathrm{hPa}$ during dust in Henan Province areas. The red dot denotes the Jiaozuo-HPU site.

of $440 \mu \mathrm{g} \mathrm{m} \mathrm{m}^{-3}$. On $6 \mathrm{Mar}$, the wind speed increased to $10 \mathrm{~m} \mathrm{~s}^{-1}$, indicating favorable diffusion conditions and leading to a sharp decrease in the concentration of $\mathrm{PM}_{10}$ $\left(116 \mu \mathrm{g} \mathrm{m}^{-3}\right)$ in Jiaozuo.

The aerosol optical properties retrieved from the CE-318 sun photometer during haze and dust episodes are exhibited in Fig. 13 (the missing data were mainly due to the accumulation of clouds). Relatively low AOD was observed on 25 Dec, being $0.38,0.25,0.21$ and 0.19 at 440, 670, 870 , and $1020 \mathrm{~nm}$, respectively (Fig. 13(a)). On that day, the $\mathrm{AE}$ was 0.84 , indicating a relatively higher proportion of coarse particles compared with the next few days that the $\mathrm{AE}$ varied from 1.34 to 1.41 , and it is also reflected by the value of $43 \%$ for $\mathrm{PM}_{2.5} / \mathrm{PM}_{10}$. The AOD showed a sustained increase from $26 \mathrm{Dec}$ to $29 \mathrm{Dec}$ and a maximum value of $\mathrm{AOD}_{440 \mathrm{~nm}}$ (2.54) was observed on 29 Dec. The mean $\mathrm{AOD}_{440 \mathrm{~nm}}$ was 1.66 during this period of haze. Meanwhile, the daily $\mathrm{AE}$ was 1.38 and the value of $\mathrm{PM}_{2.5} / \mathrm{PM}_{10}$ was larger than $60 \%$, suggesting a large quantity of fine aerosol particles caused this haze. Accordingly, fine-mode particles dominated during the haze "explosion" (27 Dec). The result is analogous to that reported by Zheng et al. (2017). On 30 Dec, the strong northwesterly $\left(>4 \mathrm{~m} \mathrm{~s}^{-1}\right)$ mentioned above in Jiaozuo favored the horizontal diffusion of aerosol particles, and the $\mathrm{AOD}_{440 \mathrm{~nm}}$ decreased to 0.57 . On the same day, the AE dropped dramatically to 0.18 , suggesting an increase in the concentration of coarse particles. It is clear from Fig. 13(c) that coarse particles were dominant on $30 \mathrm{Dec}$, with a volume of $0.27 \mu \mathrm{g} \mathrm{m}^{-3}$ for the coarse mode particles. This may have been related to elevated levels of fugitive dust under the high wind speeds (Che et al., 2014), which might explain why the minimum value of $\mathrm{SSA}_{440 \mathrm{~nm}}$ occurred on 30 Dec. During the haze "explosion" (27 Dec), the larger difference within 670-1020 nm may imply that fine aerosol particles are more sensitive to longer wavelength compared with coarse particles. Of note is that the value of AAOD during this haze was higher than on the clean day (25 Dec and 31 Dec), suggesting a large number of absorptive aerosol particles existed in the atmosphere. 

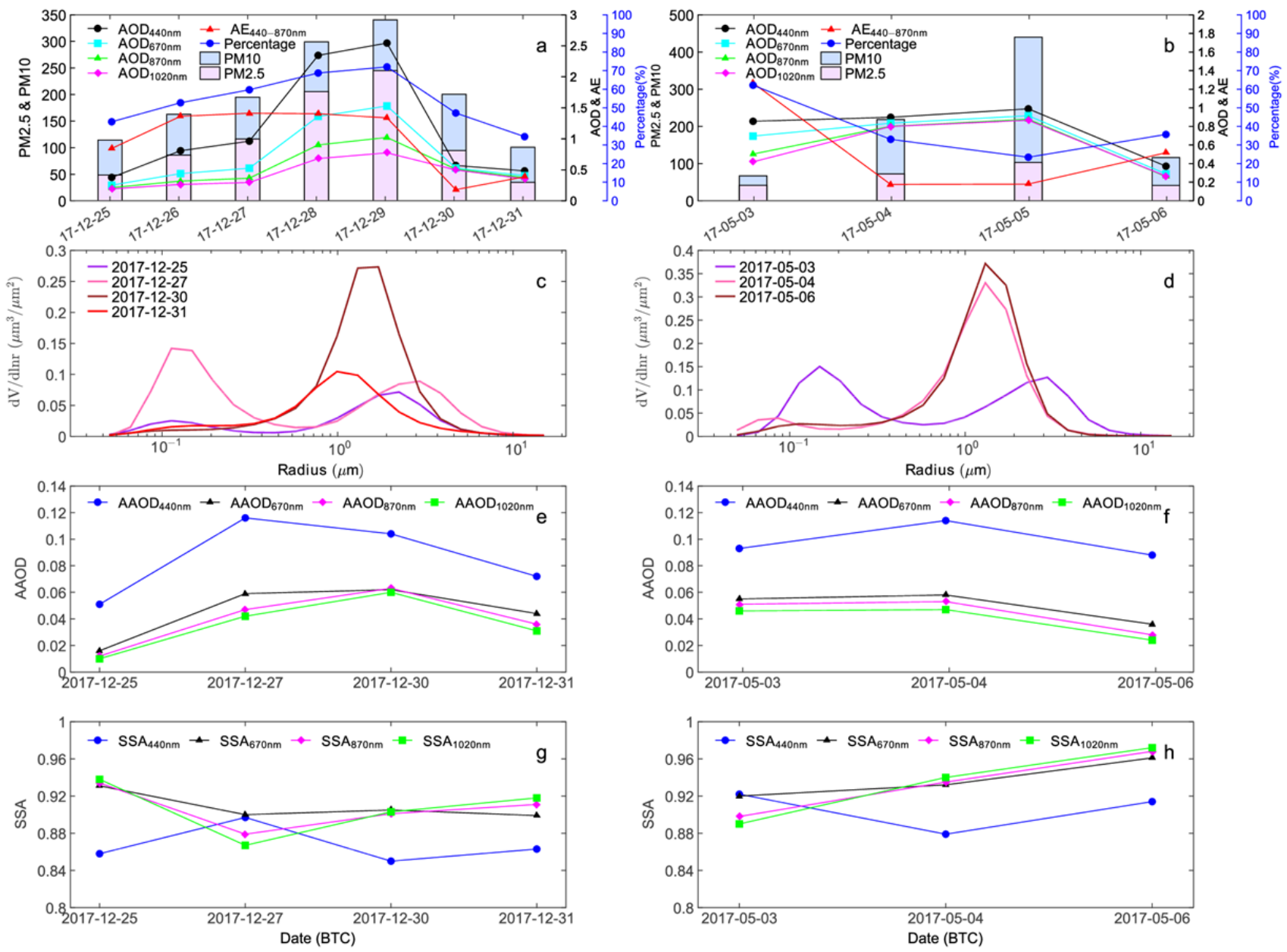

Fig. 13. Daily average values of (a, b) AOD, AE, PM concentration, (c, d) volume size distribution, (e, f) AAOD, and (g, h) SSA at Jiaozuo-HPU for haze and dust events, respectively.

The dust originating from the area to the northwest of Jiaozuo caused this dust storm in early May analyzed above. On 3 May, the day before the dust storm, the AE was 1.27 and the AOD at $440 \mathrm{~nm}$ was 0.85 . The AOD in the four bands gradually increased over the next two days, coinciding with the AOD at $440 \mathrm{~nm}$ to be 0.90 on 4 May and 0.99 on 5 May, which means that the mean AOD reached 0.95 during the dust event. Correspondingly, the AE declined sharply, reaching extremely low levels of around 0.18 because of increasing concentrations of coarse particles. Furthermore, compared with 3 May, the coarse mode particles were remarkably dominant on 4 May, the peak radius of which was around $1.3 \mu \mathrm{m}$. The volume of coarse particles was also twice as large as it was the day before, accompanied by a rise in AAOD and a drop in SSA, to 0.11 and 0.88 , respectively, at the wavelength of $440 \mathrm{~nm}$. In short, the absorptive ability of aerosol particles increased on 4 May. The high volume of coarse particles observed on 6 May might be related to dry deposition of dust particles or more fugitive dust in the atmosphere.

\section{CONCLUSION}

To the best of our knowledge, this is the first study to conduct a detailed analysis of the optical and microphysical properties of aerosols at Jiaozuo-HPU, an urban site in Henan Province with critical implications for the BeijingTianjin-Hebei region. Our study was performed between July 2016 and February 2018, during which we also analyzed cases of two typical pollution processes (dust and haze) to further examine the aerosol optical properties and pollution sources. The following conclusions can be drawn from our work:

The aerosol volume size distributions showed significant monthly and seasonal variations. Coarse-mode aerosol particles dominated in spring, with a maximum concentration of $0.16 \mu \mathrm{m}^{3} \mu \mathrm{m}^{-2}$ in May, which was possibly related to dust storms transporting large quantities of mineral dust, as well as localized winds blowing sand and soil, in this season. Owing to wet removal by abundant rainfall, only a low volume of coarse particles was observed in summer. However, summer also exhibited the maximum volume of fine-mode aerosols, the peak radii of which increased from $0.2 \mu \mathrm{m}$ in June to $0.35 \mu \mathrm{m}$ in August, which is associated with the hygroscopic growth of fine hydrophilic aerosols during high relative humidity. In addition, carbonaceous aerosols from biomass burning in June and September contributed to the volume of fine particles. 
The mean monthly values of $\mathrm{AOD}_{440 \mathrm{~nm}}$ varied from 0.57 \pm 0.41 in April to $1.11 \pm 0.59$ in July, with an annual mean of $0.84 \pm 0.55$, suggesting high aerosol loading in the Jiaozuo area. The mean $\mathrm{AOD}_{440 \mathrm{~nm}}$ values for spring, summer, autumn and winter were $0.69 \pm 0.41,1.02 \pm 0.53,0.88 \pm$ 0.54 and $0.72 \pm 0.61$, respectively. The highest AOD, which occurred in summer, was attributed to the hygroscopic growth of aerosols during enhanced relative humidity, increased agricultural activity (e.g., biomass combustion) and the formation of secondary aerosol particles (e.g., sulfate and nitrate). The mean annual AE was $1.12 \pm 0.17$, indicating that fine particles were dominant in Jiaozuo. The lowest AE occurred in spring $(0.92 \pm 0.35)$, suggesting a higher volume of coarse-mode particles during this season. The monthly SSA (AAOD $440 \mathrm{~nm}$ ) decreased (increased) from February till May, revealing the increasing absorptivity of aerosols, but increased (decreased) sharply from May till August. A distinct seasonal variation in SSA was also observed, with the highest value displayed in summer $(0.95 \pm 0.04)$ and the lowest in spring $(0.87 \pm 0.05)$. By contrast, $\mathrm{AAOD}_{440 \mathrm{~nm}}$ was higher in spring $(0.079 \pm 0.019)$ and lower in summer $(0.045 \pm 0.021)$. These seasonal differences may be attributable to the abundance of dust particles in spring, the high industrial emissions and hygroscopic growth of fine particles in summer, biomass burning in autumn and coal combustion for domestic heating in winter. The annual AAE was $1.09 \pm 0.41$, which, being close to 1 , indicated that absorbing black carbon aerosols from fossil fuel combustion were a significant factor.

The aerosols in Jiaozuo were classified into eight types according to their SSA, FMF and AE values. Due to carbonaceous aerosols from agricultural and industrial activities, absorbing aerosols, both fine and mixed, were predominant in the Jiaozuo area, accounting for $36.89 \%$ and $35.35 \%$, respectively, of the total. Obvious seasonal differences in aerosol type were found. Absorbing coarsemode particles dominated in spring (15.12\%), reflecting elevated levels of mineral dust, whereas the non-absorbing fine-mode fraction was largest in summer because of the greater abundance of sulfate and nitrate generated by intense human activity and/or photochemical reactions.

Enhanced AODs were observed during both haze and dust episodes. The mean AOD was 1.66 (0.95) on hazy (dusty) days. A high AE (1.38) was observed on hazy days, suggesting the dominance of fine-mode particles. However, the high dust concentrations on dusty days resulted in low AE values. According to WPSCF and WCWT analysis, both local emissions and pollutants from surrounding regions contributed to haze at Jiaozuo-HPU, and dust aerosols at this site mainly originated in northwestern China.

\section{ACKNOWLEDGMENTS}

This work is financially supported by grants from National Key R\&D Program Pilot Projects of China (2016YFA0601901 \& 2016YFC0203306), National Natural Science Foundation of China (41605112, 41590874, 41401403 \& 41601392), the CAMS Basis Research Project (2017Z011, 2016Z001 \& 2014R17), the Key Technology
R\&D Program of Henan Province (No. 162102310089), Doctoral Foundation of Henan Polytechnic University (No. B2016-14 and B2017-08) and Major Projects of Gaofen Satellite (No. 30-Y20A010-9007-17/18).

\section{REFERENCES}

Alam, K., Shaheen, K., Blaschke, T., Chishtie, F., Khan, H.U. and Haq, B.S. (2016). Classification of aerosols in an urban environment on the basis of optical measurements. Aerosol Air Qual. Res. 16: 2535-2549.

Arola, A., Schuster, G., Myhre, G., Kazadzis, S., Dey, S. and Tripathi, S.N. (2011). Inferring absorbing organic carbon content from aeronet data. Atmos. Chem. Phys. 11: 215-225.

Bergstrom, R.W., Pilewskie, P., Russell, P.B., Redemann, J., Bond, T.C., Quinn, P.K. and Sierau, B. (2007). Spectral absorption properties of atmospheric aerosols. Atmos. Chem. Phys. 7: 5937-5943.

Bokoye, A.I., Royer, A., O'Neill, N.T., Cliche, P., Fedosejevs, G., Teillet, P.M. and Mcarthur, L.J.B. (2001). Characterization of atmospheric aerosols across Canada from a ground-based sunphotometer network: AEROCAN. Atmos. Ocean 39: 429-456.

Chan, C.K. and Yao, X. (2008). Air pollution in megacities in China. Atmos. Environ. 42: 1-42.

Che, H.Z., Qi, B., Zhao, H.J., Xia, X.A., Eck, T.F., Goloub, P., Dubovik, O., Estelles, V., Cuevas-Agulló, E., Blarel, L., Wu, Y.F., Zhu, J., Du, R.G., Wang, Y.Q., Wang, H., Gui, K., Yu, J., Zheng, Y., Sun, T.Z., Chen, Q.L., Shi, G.Y. and Zhang, X.Y. (2018). Aerosol optical properties and direct radiative forcing based on measurements from the China Aerosol Remote Sensing Network (CARSNET) in eastern China. Atmos. Chem. Phys. 18: 405-425.

Che, H.Z., Zhang, X.Y., Li, Y., Zhou, Z.J. and Qu, J.J. (2007). Horizontal visibility trends in China 1981-2005. Geophys. Res. Lett. 34: 497-507.

Che, H.Z., Zhang, X.Y., Chen, H.B., Damiri, B., Goloub, P., Li, Z.Q., Zhang, X.C., Wei, Y., Zhou, H.G., Dong, F., Li, D.P. and Zhou, T.M. (2009). Instrument calibration and aerosol optical depth validation of the China Aerosol Remote Sensing Network. J. Geophys. Res. 114: D03206.

Che, H.Z., Wang, Y.Q. and Sun, J.Y. (2011). Aerosol optical properties at Mt. Waliguan Observatory, China. Atmos. Environ. 45: 6004-6009.

Che, H.Z., Xia, X.A., Zhu, J., Li, Z.Q., Dubovik, O., Holben, B., Goloub, P., Chen, H., Estelles, V., CuevasAgulló, E., Blarel, L., Wang, H., Zhao, H.J., Zhang, X.C., Wang, Y.Q., Sun, J.Y., Tao, R., Zhang, X.Y. and Shi, G.Y. (2014). Column aerosol optical properties and aerosol radiative forcing during a serious haze-fog month over North China Plain in 2013 based on groundbased sunphotometer measurements. Atmos. Chem. Phys. 14: 2125-2138.

Che, H.Z., Zhang, X.Y., Xia, X.A., Goloub, P., Holben, B., Zhao, H.J., Wang, Y.Q., Zhang, X.C., Wang, H., Blarel, L., Damiri, B., Zhang, R., Deng, X., Ma, Y., Wang, T., Geng, F., Qi, B., Zhu, J., Yu, J., Chen, Q. and Shi, G. 
(2015a). Ground-based aerosol climatology of China: Aerosol optical depths from the China Aerosol Remote Sensing Network (CARSNET) 2002-2013. Atmos. Chem. Phys. 15: 7619-7652.

Che, H.Z., Zhao, H.J., Xia, X.A., Wu, Y.F., Zhu, J., Ma, Y.J., Wang, Y.F., Wang, H., Wang, Y.Q., Zhang, X.Y. and Shi, G.Y. (2015b). Fine mode aerosol optical properties related to cloud and fog processing over a cluster of cities in Northeast China. Aerosol Air Qual. Res. 15: 2065-2081.

Che, H.Z., Zhao, H.J., Wu, Y.F., Xia, X.A., Zhu, J., Wang, H., Wang, Y.Q., Sun, J.Y., Yu, J., Zhang, X.Y. and Shi, G.Y. (2015c). Analyses of aerosol optical properties and direct radiative forcing over urban and industrial regions in Northeast China. Meteorol. Atmos. Phys. 127: 345354.

Cheng, T.T., Xu, C., Duan, J.Y., Wang, Y.F., Leng, C.P., Tao, J., Che, H.Z., He, Q.S., Wu, Y.F., Zhang, R.J., Li, X., Chen, J.M., Kong, L.D. and Yu, X.N. (2015). Seasonal variation and difference of aerosol optical properties in columnar and surface atmospheres over Shanghai. Atmos. Environ. 123: 315-326.

Deng, X.L., Shi, C.N., Wu, B.W., Chen, Z.H., Nie, S.P., He, D.Y. and Zhang, H. (2012). Analysis of aerosol characteristics and their relationships with meteorological parameters over Anhui province in China. Atmos. Res. 109-110: 52-63.

Dubovik, O. and King, M.D. (2000). A flexible inversion algorithm for retrieval of aerosol optical properties from Sun and sky radiance measurements. J. Geophys. Res. 105: 20673-20696.

Dubovik, O., Holben, B.N., Eck, T.F., Smirnov, A., Kaufman, Y.J., King, M.D., Tanré, D. and Slutsker, I. (2002). Variability of absorption and optical properties of key aerosol types observed in worldwide locations. $J$. Atmos. Sci. 59: 590-608.

Eck, T.F., Holben, B.N., Reid, J.S., Dubovik, O., Smirnov, A., O'Neill, N.T., Slutsker, I. and Kinne, S. (1999). Wavelength dependence of the optical depth of biomass burning, urban, and desert dust aerosols. J. Geophys. Res. 104: 31333-31349.

Eck, T.F., Holben, B.N., Dubovik, O., Smirnov, A., Goloub, P., Chen, H.B., Chatenet, B., Gomes, L., Zhang, X.Y., Tsay, S.C., Ji, Q., Giles, D. and Slutsker, I. (2005). Columnar aerosol optical properties at AERONET sites in central eastern Asia and aerosol transport to the tropical mid-Pacific. J. Geophys. Res. 110: 887-908.

Eck, T.F., Holben, B.N., Reid, J.S., Giles, D.M., Rivas, M.A., Singh, R.P., Tripathi, S.N., Bruegge, C.J., Platnick, S. and Arnold, G.T. (2012). Fog- and cloud-induced aerosol modification observed by the Aerosol Robotic Network (AERONET). J. Geophys. Res. 117: 107-116.

Fu, G.Q., Xu, W.Y., Yang, R.F., Li, J.B. and Zhao, C.S. (2014). The distribution and trends of fog and haze in the North China Plain over the past 30 years. Atmos. Chem. Phys. 14: 11949-11958.

Giles, D.M., Holben, B.N., Eck, T.F., Sinyuk, A., Smirnov, A., Slutsker, I., Dickerson, R.R., Thompson, A.M. and Schafer, J.S. (2012). An analysis of AERONET aerosol absorption properties and classifications representative of aerosol source regions. J. Geophys. Res. 117: 1-16.

Goloub, P., Li, Z., Dubovik, O., Blarel, L., Podvin, T., Jankowiak, I., Lecoq, R., Deroo, C., Chatenet, B., Morel, J.P., Cuevas, E. and Ramos, R. (2008). PHOTONS/AERONET sunphotometer network overview: Description, activities, results. Proc. SPIE 6936: 69360V.

Gui, K., Che, H.Z., Chen, Q.L., An, L.C., Zeng, Z.L., Guo, Z.Y., Zheng, Y., Wang, H., Wang, Y.Q., Yu, J. and Zhang, X.Y. (2016). Aerosol optical properties based on ground and satellite retrievals during a serious haze episode in December 2015 over Beijing. Atmosphere 7: 70.

Gyawali, M., Arnott, W.P., Lewis, K. and Moosmüller, H. (2009). In situ aerosol optics in Reno, NV, USA during and after the summer 2008 California wildfires and the influence of absorbing and non-absorbing organic coatings on spectral light absorption.Atmos. Chem. Phys. 9: 8007-8015.

Hansen, J., Sato, M., Ruedy, R., Lacis, A. and Oinas, V. (2000). Global warming in the twenty-first century: An alternative scenario. Proc. Natl. Acad. Sci. USA 97: 9875-9880.

He, L.J., Wang, L.C., Lin, A.W., Zhang, M., Bilal, M. and Tao, M.H. (2017). Aerosol optical properties and associated direct radiative forcing over the Yangtze River basin during 2001-2015. Remote Sens. 9: 746.

He, L.J., Wang, L.C., Lin, A.W., Zhang, M., Bilal, M. and Wei, J. (2018). Performance of the NPP-VIIRS and aqua-MODIS aerosol optical depth products over the Yangtze River Basin. Remote Sens. 10: 117.

He, Q.S., Li, C.C., Geng, F.H., Yang, H.Q., Li, P.R., Li, T.T., Liu, D.W. and Pei, Z. (2012a). Aerosol optical properties retrieved from Sun photometer measurements over Shanghai, China. J. Geophys. Res. 117: D16204.

He, Q.S., Li, C.C., Geng, F.H., Lei, Y. and Li, Y.H. (2012b). Study on long-term aerosol distribution over the land of East China using MODIS data. Aerosol Air Qual. Res. 12: 304-319.

Hennigan, C.J., Bergin, M.H., Dibb, J.E. and Weber, R.J. (2008). Enhanced secondary organic aerosol formation due to water uptake by fine particles. Geophys. Res. Lett. 35: L18801.

Holben, B.N., Eck, T.F., Slutsker, I., Tanré, D., Buis, J.P., Setzer, A., Vermote, E., Reagan, J.A., Kaufman, Y.J., Nakajima, T., Lavenu, F., Jankowia, I. and Smirnov, A. (1998). AERONET - A federated instrument network and data archive for aerosol characterization. Remote Sens. Environ. 66: 1-16.

Huang, X., Ding, A.J., Liu, L.X., Liu, Q., Ding, K., Niu, X.R., Nie, W., Xu, Z., Chi, X.G., Wang, M.H., Sun, J.N., Guo, W.D. and Fu, C.B. (2016). Effects of aerosolradiation interaction on precipitation during biomassburning season in East China. Atmos. Chem. Phys. 16: 10063-10082.

IPCC (2013). Climate change 2013: The scientifical basis. Cambridge University Press, New York, NY, USA.

Kaufman, Y.J., Tanré, D., Remer, L.A., Vermote, E.F., Chu, A. and Holben, B.N. (1997). Operational remote sensing 
of tropospheric aerosol over land from EOS moderate resolution imaging spectroradiometer. J. Geophys. Res. 102: 17051-17067.

Kroll, J.H. and Seinfeld, J.H. (2008). Chemistry of secondary organic aerosol: Formation and evolution of low-volatility organics in the atmosphere. Atmos. Environ. 42: 3593-3624.

Kumar, M., Singh, R.S. and Banerjee, T. (2015). Associating airborne particulates and human health: Exploring possibilities. Environ. Int. 84: 201-202.

Lack, D.A. and Cappa, C.D. (2010). Impact of brown and clear carbon on light absorption enhancement, single scatter albedo and absorption wavelength dependence of black carbon. Atmos. Chem. Phys. 10: 4207-4220.

Lee, J., Kim, J., Song, C.H., Kim, S.B., Chun, Y., Sohn, B.J. and Holben, B.N. (2010). Characteristics of aerosol types from AERONET sunphotometer measurements. Atmos. Environ. 44: 3110-3117.

Li, J.X., Li, P.R., Yuan, L., Yin, Y., Wang, Z.Z., Li, J., Li, Y.N., Ren, G. and Cai, Z.X. (2017). Physical and optical properties of atmospheric aerosols in summer at a Suburban site in North China. Aerosol Air Qual. Res. 17: 1474-1488.

Li, S.S., Ma, Z.W., Xiong, X.Z., Christiani, D.C., Wang, Z.X. and Liu, Y. (2016). Satellite and ground observations of severe air pollution episodes in the winter of 2013 in Beijing, China. Aerosol Air Qual. Res. 16: 977-989.

Liu, B.M., Ma, Y.Y., Gong, W., Zhang, M. and Yang, J. (2018). Study of continuous air pollution in winter over Wuhan based on ground-based and satellite observations. Atmos. Pollut. Res. 9: 156-165.

Liu, P.F., Zhao, C.S., Zhang, Q., Deng, Z.Z., Huang, M.Y., Ma, X.C. and Tie, X.X. (2009). Aircraft study of aerosol vertical distributions over Beijing and their optical properties. Tellus B 61: 756-767.

Liu, Q., Ding, W.D., Xie, L., Zhang, J.Q., Zhu, J., Xia, X.A., Liu, D.Y., Yuan, R.M. and Fu, Y.F. (2017). Aerosol properties over an urban site in central East China derived from ground sun-photometer measurements. Sci. China Earth Sci. 60: 297-314.

Liu, Z.Y., Liu, D., Huang, J.P., Vaughan, M.A., Uno, I., Sugimoto, N., Kittaka, C., Trepte, C.R., Wang, Z.E., Hostetler, C.A. and Winker, D.M. (2008). Airborne dust distributions over the Tibetan Plateau and surrounding areas derived from the first year of CALIPSO lidar observations. Atmos. Chem. Phys. 8: 5045-5060.

Ma, N., Zhao, C.S., Nowak, A., Müller, T., Pfeifer, S., Cheng, Y.F., Deng, Z.Z., Liu, P.F., Xu, W.Y., Ran, L., Yan, P., Göbel, T., Hallbauer, E., Mildenberger, K., Henning, S., Yu, J., Chen, L.L., Zhou, X.J., Stratmann, F. and Wiedensohler, A. (2011). Aerosol optical properties in the North China Plain during HaChi campaign: an insitu optical closure study. Atmos. Chem. Phys. 11: 59595973.

Nakajima, T., Sekiguchi, M., Takemura, T., Uno, I., Higurashi, A., Kim, D., Sohn, B.J., Oh, S.N., Nakajima, T.Y. and Ohta, S. (2003). Significance of direct and indirect radiative forcings of aerosols in the East China Sea region. J. Geophys. Res. 108: 2139-2146.
Ngan, F., Stein, A. and Draxler, R. (2015). Inline coupling of WRF-HYSPLIT: Model development and evaluation using tracer experiments. J. Appl. Meteorol. Clim. 54: 1162-1176.

Omar, A.H., Winker, D.M., Vaughan, M.A., Hu, Y.X., Trepte, C.R., Ferrare, R.A., Lee, K.P. and Hostetler, C.A. (2009). The CALIPSO automated aerosol classification and lidar ratio selection algorithm. J. Atmos. Ocean. Technol. 26: 1994-2014.

Pope, C.A. and Dockery, D.W. (2006). Health effects of fine particulate air pollution: Lines that connect. J. Air Waste Manage. Assoc. 56: 709-742.

Qi, B., Hu, D.Y., Che, H.Z., Du, R.G., Wu, Y.F., Xia, X.A., Zha, B., Liu, J., Niu, Y.W., Wang, H., Zhang, X.Y. and Shi, G.Y. (2016). Seasonal variation of aerosol optical properties in an urban site of the Yangtze Delta Region of China. Aerosol Air Qual. Res. 16: 2884-2896.

Qin, W.M., Wang, L.C., Lin, A.W., Zhang, M. and Bilal, M. (2018). Improving the estimation of daily aerosol optical depth and aerosol radiative effect using an optimized artificial neural network. Remote Sens. 10: 1022.

Russell, P.B., Bergstrom, R.W., Shinozuka, Y., Clarke, A.D., DeCarlo, P.F., Jimenez, J.L., Livingston, J.M., Redemann, J., Dubovik, O. and Strawa, A. (2010). Absorption Angstrom Exponent in AERONET and related data as an indicator of aerosol composition. Atmos. Chem. Phys. 10: 1155-1169.

Schwartz, S.E. and Andreae, M.O. (1996). Uncertainty in climate change caused by aerosols. Science 272: 11211122.

Seneviratne, S., Handagiripathira, L., Sanjeevani, S., Madusha, D., Waduge, V.A.A., Attanayake, T., Bandara, D. and Hopke, P.K. (2017). Indentification of sources of fine particulate matter in Kandy, Sri Lanka. Aerosol Air Qual. Res. 17: 476-484.

Shen, X.J., Sun, J.Y., Zhang, X.Y., Zhang, Y.M., Zhang, L., Che, H.C., Ma, Q.L., Yu, X.M., Yue, Y. and Zhang, Y.W. (2015). Characterization of submicron aerosols and effect on visibility during a severe haze-fog episode in Yangtze River Delta, China. Atmos. Environ. 120: $307-$ 316.

Smirnov, A., Holben, B.N., Eck, T.F., Dubovik, O. and Slutsker, I. (2000). Cloud screening and quality control algorithms for the AERONET database. Remote Sens. Environ. 73: 337-349.

Sun, T.Z., Che, H.Z., Qi, B., Wang, Y.Q., Dong, Y.S., Xia, X.A., Wang, H., Gui, K., Zheng, Y., Zhao, H.J., Ma, Q.L., Du, R.G. and Zhang, X.Y. (2018). Aerosol optical characteristics and their vertical distributions under enhanced haze pollution events: Effect of the regional transport of different aerosol types over eastern China. Atmos. Chem. Phys. 18: 2949-2971.

Tao, M.H., Chen, L.F., Wang, Z.F., Ma, P.F., Tao, J.H. and Jia, S.L. (2014). A study of urban pollution and haze clouds over northern China during the dusty season based on satellite and surface observations. Atmos. Environ. 82: 183-192.

Torres, O., Bhartia, P.K., Sinyuk, A., Welton, E.J. and 
Holben, B. (2005). Total Ozone Mapping Spectrometer measurements of aerosol absorption from space: Comparison to SAFARI 2000 ground-based observations. J. Geophys. Res. 110: D10S18.

Twomey, S.A., Piepgrass, M. and Wolfe, T.L. (1984). An assessment of the impact of pollution on global cloud albedo. Tellus $B$ 36: 356-366.

Wang, L.C., Gong, W., Xia, X.A., Zhu, J., Li, J. and Zhu, Z.M. (2015a). Long-term observations of aerosol optical properties at Wuhan, an urban site in Central China. Atmos. Environ. 101: 94-102.

Wang, L.C., Gong, W., Singh, R.P., Xia, X.A., Che, H.Z., Zhang, M. and Lin, H. (2015b). Aerosol optical properties over Mount Song, a rural site in Central China. Aerosol Air Qual. Res. 15: 2051-2064.

Wang, P., Che, H.Z., Zhang, X.C., Song, Q.1., Wang, Y.Q., Zhang, Z.H., Dai, X. and Yu, D.J. (2010). Aerosol optical properties of regional background atmosphere in Northeast China. Atmos. Environ. 44: 4404-4412.

Wang, X., Liu, J., Che, H.Z., Ji, F. and Liu, J.J. (2018). Spatial and temporal evolution of natural and anthropogenic dust events over northern China. Sci. Rep. 8: 2141.

Wang, Y.Q., Zhang, X.Y. and Arimoto, R. (2006). The contribution from distant dust sources to the atmospheric particulate matter loadings at $\mathrm{XiAn}$, China during spring. Sci. Total Environ. 368: 875-883.

Wang, Y.S., Xin, J.Y., Li, Z.Q., Wang, S.G., Wang, P.C., Hao, W.M., Nordgren, B.L., Chen, H.B., Wang, L.L. and Sun, Y. (2011). Seasonal variations in aerosol optical properties over China. J. Geophys. Res. 116: D18209.

Xia, X.A., Li, Z.Q., Holben, B., Wang, P., Eck, T., Chen, H., Cribb, M. and Zhao, Y. (2007). Aerosol optical properties and radiative effects in the Yangtze Delta region of China. J. Geophys. Res. 112: D22S12.

Xia, X.A., Che, H.Z., Zhu, J., Chen, H.B., Cong, Z.Y., Deng, X.J., Fan, X.H., Fu, Y.F., Goloub, P., Jiang, H., Liu, Q., Mai, B.R., Wang, P.C., Wu, Y.F., Zhang, J.Q., Zhang, R.J. and Zhang, X.Y. (2016). Ground-based remote sensing of aerosol climatology in China: Aerosol optical properties, direct radiative effect and its parameterization. Atmos. Environ. 124: 243-251.

Xin, Y. (2016). Identification of long-range transport pathways and potential sources of $\mathrm{PM}_{10}$ in Tibetan Plateau uplift area: Case study of Xining, China in 2014. Aerosol Air Qual. Res. 16: 1044-1054.

Yan, Y., Sun, Y.B., Weiss, D., Liang, L.J. and Chen, H.Y. (2015). Polluted dust derived from long range transport as a major end member of urban aerosols and its implication of non point pollution in northern China. Sci. Total Environ. 506: 538-545.

Yang, M., Howell, S.G., Zhuang, J. and Huebert, B.J. (2009). Attribution of aerosol light absorption to black carbon, brown carbon, and dust in China - interpretations of atmospheric measurements during EAST-AIRE. Atmos. Chem. Phys. 9: 2035-2050.
Zhang, M., Wang, L.C., Gong, W., Ma, Y.Y. and Liu, B.M. (2017a). Aerosol optical properties and direct radiative effects over Central China. Remote Sens. 9: 997.

Zhang, M., Ma, Y.Y., Gong, W., Wang, L.C., Xia, X.A., Che, H.Z., Hu, B. and Liu, B.M. (2017b). Aerosol radiative effect in UV, VIS, NIR, and SW spectra under haze and high-humidity urban conditions. Atmos. Environ. 166: 9-21.

Zhang, M., Ma, Y.Y., Wang, L.C., Gong, W., Hu, B. and Shi, Y.F. (2018). Spatial-temporal characteristics of aerosol loading over the Yangtze River Basin during 2001-2015. Int. J. Climatol. 38: 2138-2152.

Zhang, X.Y., Arimoto, R., Zhu, G.H., Chen, T. and Zhang, G.Y. (1998). Concentration, size-distribution and deposition of mineral aerosol over Chinese desert regions. Tellus $B$ 50: 317-330.

Zhao, H.J., Che, H.Z., Ma, Y.J., Xia, X.A., Wang, Y.F., Wang, P. and Wu, X.C. (2015). Temporal variability of the visibility, particulate matter mass concentration and aerosol optical properties over an urban site in Northeast China. Atmos. Res. 166: 204-212.

Zhao, H.J., Che, H.Z., Zhang, X.Y., Ma, Y.J., Wang, Y.F., Wang, X.X., Liu, C., Hou, B. and Che, H.C. (2013). Aerosol optical properties over urban and industrial region of Northeast China by using ground-based sunphotometer measurement. Atmos. Environ. 75: 270-278.

Zhao, H.J., Che, H.Z., Wang, Y.Q., Dong, Y.S., Ma, Y.J., Li, X.X., Hong, Y., Yang, H.B., Liu, Y.C., Wang, Y.F., Gui, K., Sun, T.Z., Zheng, Y. and Zhang, X.Y. (2018). Aerosol vertical distribution and typical air pollution episodes over Northeastern China during 2016 analysed by ground-based lidar. Aerosol Air Qual. Res. 18: 918937.

Zheng, C.W., Zhao, C.F., Zhu, Y.N., Wang, Y., Shi, X.Q., Wu, X.L., Chen, T.M., Wu, F. and Qiu, Y.M. (2017). Analysis of influential factors for the relationship between $\mathrm{PM}_{2.5}$ and AOD in Beijing. Atmos. Chem. Phys. 17: $13473-13489$.

Zheng, Y., Che, H.Z., Yang, L.K., Chen, J., Wang, Y.Q., Xia, X.A., Zhao, H.J., Wang, H., Wang, D.Y., Gui, K., An, L.C., Sun, T.Z., Yu, J., Kuang, X., Li, X., Sun, E.W., Zhao, D.P., Yang, D.S., Guo, Z.Y., Zhao, T.L. and Zhang, X.Y. (2017). Optical and radiative properties of aerosols during a severe haze episode over the North China Plain in December 2016. J. Meteorolog. Res. 31: 1045-1061.

Zhu, J., Che, H.Z., Xia, X.A., Chen, H.B., Goloub, P. and Zhang, W.X. (2014). Column-integrated aerosol optical and physical properties at a regional background atmosphere in North China Plain. Atmos. Environ. 84: 54-64.

Received for review, June 14, 2018 Revised, December 2, 2018 Accepted, January 4, 2019 